\title{
SIKAP PEMILIK LAHAN TERHADAP ALIH FUNGSI LAHAN DI DESA KALASEY SATU
}

\author{
Saiful Sarayar \\ Rine Kaunang \\ Mex L. Sondakh
}

\begin{abstract}
This study aims to determine the attitude of landowners against land conversion in the village Kalasey One, Minahasa. This research was conducted by using primary data obtained from interviews on a sample of attitudes concerning land owners who've experienced over the land by using a questionnaire that has been prepared. Secondary data were obtained from the Office of the Central Statistics Agency (BPS) and the Office of Manado City Government Kalasey Village One. The results showed that the attitude of landowners against land conversion mostly to take place quickly and the conversion is done by first over land tenure. Land converted generally used to build houses and residential areas. Factors that cause land conversion categorized into internal factors such as the pressing economic needs and the desire to change the fate, as well as external factors such as population growth and government policies. Meanwhile land use also has a positive effect, namely the presence of housing construction resulted in the development of rural economy. The attitude of landowners against land conversion is at an index number of 73.73 percent means included in either category.
\end{abstract}

Keywords: attitude, landowners, land conversion, Kalasey 1 Village.

\section{ABSTRAK}

Penelitian ini bertujuan untuk mengetahui sikap pemilik lahan terhadap alih fungsi lahan di Desa Kalasey Satu, Minahasa. Penelitian ini dilaksanakan dengan mengunakan data primer diperoleh dari wawancara langsung pada sampel menyangkut sikap pemilik lahan yang pernah mengalami alih fungsi lahan dengan menggunakan kuesioner yang telah disiapkan. Data sekunder yang diperoleh dari Kantor Badan Pusat Statistik (BPS) Kota Manado dan Kantor Pemerintah Desa Kalasey Satu. Hasil penelitian menunjukkan bahwa sikap pemilik lahan terhadap alih fungsi lahan sebagian besar berlangsung secara cepat dan alih fungsi dilakukan dengan cara alih penguasaan tanah terlebih dahulu. Lahan yang dialihfungsikan pada umumnya dimanfaatkan untuk mendirikan rumah dan wilayah perumahan. Faktor yang menyebabkan alih fungsi lahan dikategorikan menjadi faktor internal berupa kebutuhan ekonomi yang mendesak dan keinginan untuk merubah nasib, serta faktor eksternal berupa pertambahan penduduk dan kebijakan pemerintah. Sementara itu alih fungsi lahan juga mempunyai dampak positif, yaitu dengan adanya pembangunan perumahan mengakibatkan terjadinya perkembangan dalam perekonomian di desa. Sikap pemilik lahan terhadap alih fungsi lahan berada pada titik angka indeks 73,73 persen artinya termasuk dalam kategori baik.

Kata Kunci: sikap, pemilik lahan, alih fungsi lahan, Desa Kalasey 1

\section{PENDAHULUAN}

\section{Latar Belakang}

Indonesia termasuk negara kepulauan yang memiliki kekayaan alam dan sumberdaya yang melimpah. Beragamnya kekayaan yang dimiliki ini berpotensi meningkatkan kesejahteraan masyarakat dan perekonomian negara secara menyeluruh. Banyak sektor seperti bidang pertanian, pertambangan, industri, serta pariwisata yang berperan dalam kegiatan perekonomian Indonesia.

Sektor-sektor inilah yang selama ini dapat dikembangkan secara optimal dan dapat dimanfaatkan oleh seluruh lapisan masyarakat.
Sektor pertanian memiliki peran yang penting dalam kegiatan perekonomian nasional seperti dalam hal menyerap tenaga kerja, menyumbang Produk Domestik Bruto (PDB), sumber devisa, bahan baku industri, sumber bahan pangan dan gizi, serta pendorong bergeraknya sektor-sektor ekonomi lainya. Menurut Kuznets (1966), dalam Andhika (2013) sektor pertanian mengkontribusikan terhadap pertumbuhan dan pembangunan ekonomi nasional dalam 4 bentuk yaitu :

1. Kontribusi Produk contohnya menyediakan bahan baku untuk industri manufaktur seperti: industri tekstil, makanan, minuman, dan lainlain. 
2. Kontribusi pasar contohnya pembentukan pasar domestik untuk barang industri dan konsumsi.

3. Kontribusi faktor produksi menyebabkan penurunan peranan pertanian di pembangunan ekonomi, maka terjadi transfer surpus modal dan sektor pertanian ke sektor lain.

4. Kontribusi devisa pertanian sebagai sumber paling penting bagi surplus neraca perdagangan melalui ekspor produk pertanian dan produk pertanian yang menggantikan produk impor.

Produk Domestik Bruto (PDB) pada tahun 2015 tumbuh sebesar 4,79 persen dibandingkan dengan tahun 2014. Pertumbuhan terjadi pada semua sektor ekonomi tidak terkecuali pada sektor pertanian dengan laju pertumbuhan sebesar 4,02 persen. Walaupun peran pertanian memiliki arti penting bagi pembangunan nasional dan terus mengalami pertumbuhan setiap tahunnya, namun laju pertumbuhannya tidak sebesar sektor-sektor lainnya.Laju pertumbuhan tertinggi pada Sektor Pengangkutan dan Komunikasi sebesar 10,06 persen diikuti oleh Sektor Perdagangan sebesar 2,47 persen (BPS) 2015.

Alih fungsi lahan pertanian sebenarnya bukan masalah baru. Sejalan dengan adanya peningkatan jumlah penduduk serta meningkatnya kebutuhan infrastruktur seperti, perumahan, jalan, industri, perkantoran, dan bangunan lain menyebabkan kebutuhan akan lahan meningkat. Selain itu, pertumbuhan ekonomi yang tinggi menyebabkan pertumbuhan yang sangat cepat di beberapa sektor ekonomi. Pertumbuhan tersebut juga membutuhkan lahan yang lebih luas sehingga terjadi peningkatan kebutuhan lahan untuk pembangunan, sementara ketrsediaan lahan relatif tetap menyebabkan persaingan dalam pemanfaatanlahan. Kebanyakan lahan yang dialihfungsikan umumnya adalah lahan-lahan pertanian karena land rent (sewa lahan). Menurut Barlowe dalam Yudhistira (2013), sewa ekonomi lahan (land rent) mengandung pengertian nilai ekonomi yang diperoleh oleh satu bidang lahan bila lahan tersebut digunakan untuk kegiatan proses produksi. Land rent lahan pertanian relatif lebih tinggi penggunaannya untuk non-pertanian dibandingkan dengan lahan pertanian yang dikelola oleh petani (Putri 2009 dalam Puspasari 2012).

Fenomena alih fungsi lahan pertanian merupakan dampak dari transformasi sruktur ekonomi (pertanian ke industri), dan demografi (pedesaan ke perkotaan) yang pada akhirnya mendorong transformasi sumberdaya lahan dari pertanian ke non-pertanian (Supriyadi 2004 dalam Puspasari 2012). Persoalan ini harus dicarikan solusi pemecahannya karena melihat juga dampak yang ditimbulkan dari alih fungsi lahan ini dapat merugikan petani khususnya dan masyarakat Indonesia pada umumnya. Pertambahan penduduk yang mempengaruhi luasan lahan yang tersedia dapat mendorong perubahan penggunaan lahan untuk memenuhi kebutuhan penduduk yang tidak terbatas. Menurut Utomo dalam (Andihka 2013), alih fungsi lahan merupakan perubahan fungsi sebagian atau seluruh kawasan lahan dari fungsinya semula (seperti yang direncanakan) menjadi fungsi lain yang menjadi dampak negatif (masalah) terhadap lingkungan dan potensi lahan itu sendiri. Nilai dan harga lahan di sekitar daerah perkotaan yang semakin tinggi menyebabkan adanya pergeseran aktivitas ekonomi dan penguasaan lahan oleh pihak pengembang atau para investor sehingga arahan pengembangannya pun sebisa mungkin disesuaikan dengan keinginan pihak pengembang tersebut (Marliza 2008) dalam (Andihka 2013).

Penelitian ini menjadi penting karena alih fungsi lahan semakin bertambah. Kondisi ini terlihat jelas di Desa Kalasey Satu Kecamatan Mandolang yang terus menerus melakukan alih fungsi lahan. Desa Kalasey Satu merupakan salah satu wilayah yang memiliki potensi sebagai wilayah pertanian. Namun seiring dengan perkembangan zaman, di kecamatan Mandolang ini telah mengalami perubahan kebutuhan lahan menjadi non pertanian. Berkaitan dengan perubahan kebutuhan lahan dari lahan pertanian menjadi non pertanian, penting untuk dilihat lebih jauh mengenai sikap pemilik lahan terhadap alih fungsi lahan yang dilakukan. Sikap pemilik lahan dilihat untuk mengetahui penilaian pemilik lahan terhadap alih fungsi lahan pertanian yang terus dilakukan oleh pihak luar. Hal ini didasari oleh dugaan bahwa pembangunan perumahan merupakan suatu bertambahnya faktor ekonomi, kependudukan, bagi mereka (pemilik lahan) untuk melakukan alih fungsi lahan pertanian secara langsung. Sikap ini ditunjukkan dengan sikap positif dan sikap negatif. Sikap positif ditunjukkan oleh pemilik lahan apabila mereka setuju terhadap alih fungsi lahan pertanian. Sebaliknya, sikap negatif ditunjukkan oleh pemilik lahan apabila mereka tidak setuju terhadap alih fungsi lahan 
pertanian. Sikap negatif memiliki pengertian bahwa mereka tidak siap menerima perubahan dan menginginkan kondisi semula. Artinya, alih fungsi lahan pertanian untuk pembangunan tidak menjamin kesejahteraan bagi seluruh masyarakat khususnya bagi pemilik lahan.

\section{Perumusan Masalah}

Berdasarkan latar belakang, maka yang menjadi permasalahan dalam penelitian ini adalah bagaimana sikap pemilik lahan terhadap ahli fungsi lahan di Desa Kalasey Satu.

\section{Tujuan}

Berdasarkan perumusan masalah tersebut, maka tujuan penelitian ini adalah untuk mengetahui bagaimana sikap pemilik lahan terhadap alih fungsi lahan di Desa Kalasey Satu.

\section{Manfaat Penulis}

Hasil penelitian ini diharapkan dapat menjadi sumbangan pengetahuan bagi pemerintah dan masyarakat sebagai bahan pertimbangan dalam mengambil keputusan untuk mengalih fungsikan lahan.

\section{METODOLOGI PENELITIAN}

\section{Tempat dan Lokasi Penelitian}

Penelitian ini dilaksanakan di Desa Kalasey Satu Kecamatan Mandolang Dua Kabupaten Minahasa selama (dua) bulan mulai dari bulan Maret sampai bulan Juni 2016 yaitu dari persiapan, pengambilan data sampai pada penyusunan laporan hasil penelitian.

\section{Metode Pengumpulan Data}

Metode pengumpulan data dilakukan dengan menggunakan data primer dan data sekunder. Data primer diperoleh dari wawancara langsung dengan sampel sikap pemilik lahan yang pernah mengalami alih fungsi lahan dengan menggunakan kusioner yang telah disiapkan. Data sekunder yang diperoleh dari BPS Kota Manado, pemerintah Desa Kalasey Satu.

\section{Metode Pengambilan Sampel}

Metode pengambilan sampel dalam penelitian ini adalah metode purposive sampling, dimana peneliti memilih anggota sampel yang mempunyai lahan tertentu yang disengaja oleh peneliti, karena hanya sampel tersebut saja yang mewakili atau dapat memberikan informasi untuk menjawab masalah penelitian. Jumlah responden yaitu sebesar 30 anggota keluaraga yang memilki lahan pertanian.

\section{Konsep Pengukuran Variabel}

Variabel-variabel yang dikaji dalam penelitian ini adalah :

1. Karakteristik Responden, mencakup

1) Umur, yaitu umur pemilik lahan yang dinyatakan dalam tahun.

2) Tingkat Pendidikan, dilihat dari pendidikan terakhir yang ditempuh responden diukur dalam tahun.

3) Pekerjaan, dilihat dari profesi responden saat wawancara dilaksanakan.

4) Luas lahan yang dimiliki, jumlah tanggunga keluarga.

2. Penelitian ini merumuskan, dilihat dari sikap pemilik lahan terhadap alih fungsi lahan, yaitu:

1. Sikap pemilik lahan, Pengukuran dilakukan dengan menggunakan skor dilihat dari aspek pikiran (kognitif), aspek perasaan (afektif), dan kecenderungan bertindak (konatif).

\section{Analisis Data}

Penelitian ini menggunakan metode analisis data, yaitu metode analisis kualitatif deskriptif. Metode analisis deskriptif adalah metode penelitian yang melibatkan analisis data berupa deskriptif dan data tersebut tidak secara langsung dapat dikuantifikasi. Analisis deskriptif merupakan metode pencarian fakta dengan interpretasi yang tepat mengenai masalah-masalah yang ada dalam masyarakat, tata cara yang berlaku, serta situasi-situasi tertentu termasuk tentang hubungan, kegiatan, sikap, pandangan, serta proses yang sedang berlangsung dan pengaruh dari suatu fenomena.

Dengan menggunakan analisis deskriptif ini maka akan diperoleh gambaran mengenai sikap pemilik lahan terhadap alih fungsi lahan. Untuk mengetahui pengaruh sikap terhadap alih fungsi lahan di gunakan Skala Likert.

Analisis data dalam penelitian ini adalah deskriptif dengan menggunakan daftar tabel dan angka. Untuk mengukur sikap akan disusun 15 pernyataan dengan total responden 30. Setiap jawaban dihubungkan dengan bentuk pernyataan 
atau dukungan sikap yang diungkapkan dengan kata-kata berikut:

$\begin{array}{ll}\text { Sangat Setuju } & \text { Skor 5 } \\ \text { Setuju } & \text { Skor 4 } \\ \text { Ragu-ragu } & \text { Skor 3 } \\ \text { Sangat tidak setuju } & \text { Skor 2 } \\ \text { Tidak setuju } & \text { Skor 1 }\end{array}$

Dengan cara perhitungan skor masing-masing pernyataan. Jumlah Skor Tiap Kriterium = Capaian Skor x Jumlah Responden :

$\mathrm{S}_{5}=5 \times 30=150$

$\mathrm{S}_{4}=4 \times 30=120$

$\mathrm{S}_{3}=3 \times 30=90$

$\mathrm{S}_{2}=2 \times 30=60$

$\mathrm{S}_{1}=1 \times 30=30$

Jumlah skor ideal untuk siap pernyataan (Skor Tertinggi) $=150$

Jumlah skor terendah $=30$

Dengan Interpretasi nilai:

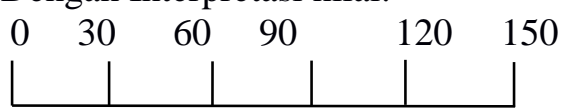

\section{STS TS RR S SS}

Cara perhitungan skor keseluruhan untuk mengetahui sikap. Jumlah Skor Seluruh Kriterium = Capaian Jumlah Skor $\mathrm{x}$ Jumlah Responden $\mathrm{X}$

Instrument pernyataan untuk :

$\mathrm{S}_{5}=5 \times 30 \times 15=2.250$

$\mathrm{S}_{4}=4 \times 30 \times 15=1.800$

$\mathrm{S}_{3}=3 \times 30 \times 15=1.350$

$\mathrm{S}_{2}=2 \times 30 \times 15=900$

$\mathrm{S}_{1}=1 \times 30 \times 15=450$

Jumlah skor ideal untuk keseluruhan pernyataan $=2.250$ (Tertinggi)

Jumlah skor terendah $=450$ (Rendah)

Dengan Interpretasi nilai :

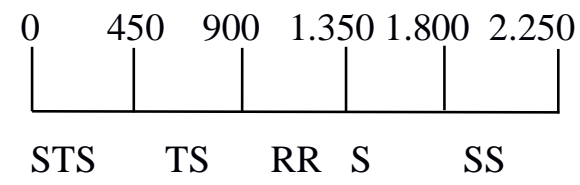

Analisis data yang digunakan merupakan analisis deskriptif yang analisis dengan menggunakan skala pengukuran sikap Likert Scale dimana menurut Ridwan (2010) dalam buku Rumus dan Data dalam Analisis Statistika, adalah sebagai berikut :
Tingkat Sikap $=\frac{\text { JumlahSkorHasilPengumpulanData }}{\text { JumlahSkorIdeal (Tertinggi) }} \times 100 \%$

Dengan Interpretasi nilai :

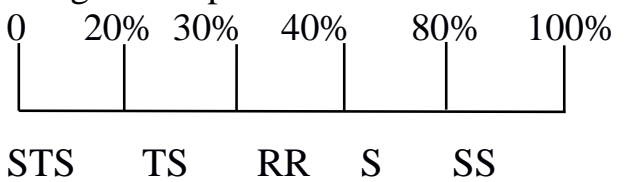

$\begin{array}{ll}\text { Angka 0\%-20\% } & =\text { Sangat tidak setuju } \\ \text { Angka 21\%-40\% } & =\text { Tidak setuju } \\ \text { Angka 41\%-60\% } & =\text { Ragu-ragu } \\ \text { Angka 61\%-80\% } & =\text { Setuju } \\ \text { Angka } 81 \%-100 \% & =\text { Sangat setuju }\end{array}$

\section{HASIL DAN PEMBAHASAN}

\section{Gambaran Umum Wilayah Penelitian}

Kecamatan Mandolang adalah salah satu Kecamatan di Kabupaten Minahasa Provinsi Sulawesi Utara, terletak antara $1^{0} 399^{\prime} 59.90$ "N Lintang Utara dan $124^{0} 47^{\prime 22}$.61'E Bujur Timur dengan Ibukota Kecamatan adalah Desa Tateli berjarak sekitar $48 \mathrm{~km}$ dari Tondano, kota ibukota Kabupaten Minahasa. Pada tahun 2012 oleh Bupati Minahasa mengeluarkan surat keputusan dalam rangka pemekaran Kecamatan Pineleng menjadi dua kecamatan yaitu Kecamatan Pineleng dan Kecamtan Mandolang. Di mana secara geografis Kecamatan Mandolang terletak di daerah pesisir pantai dan bersebelahan dengan Ibu Kota Provinsi Sulawesi Utara yaitu Kota Tondano. Desa Kalasey Satu merupakan Desa yang terletak di pesisir pantai dan berbatasan dengan laut Sulawesi. Selain itu, letak Desa Kalasey Satu berbatasan dengan ibu Kota Provinsi Sulawesi Utara yaitu Kota Manado. Batas-batas wilayah yang lebih lengkap Kecamatan Mandolang sebagai berikut:
- Sebelah Utara
: Laut Sulawesi
- Sebelah Barat
: Koha
- Sebelah Selatan
: Sea, Kalasey Dua
- Sebelah Timur
: Malalayang

\section{Luas Wilayah Menurut Desa}

Persentase luas desa Kecamatan Mandolang terlihat pada tabel 2, dimana desa terluas adalah Desa Koha dan desa yang terkecil persentase luasnya adalah Desa Kalasey Satu. Sebelah utara Kecamatan Mandolang berbatasan dengan laut Sulawesi, sebelah timur selatan dengan Kota Manado, sebelah selatan 
dengan Kecamatan Pineleng dan sebelah barat berbatasan dengan kecamatan Tombariri Timur.

Tabel 1. Luas Wilayah Menurut Desa, 2015

\begin{tabular}{clc}
\hline No & \multicolumn{1}{c}{ Desa } & Luas $(\mathrm{Ha})$ \\
\hline 1. & Agotey & 320 \\
2. & Koha & 2950 \\
3. & Tateli Weru & 500 \\
4. & Tateli & 800 \\
5. & Kalasey Dua & 256 \\
6. & Kalasey Satu & 125 \\
7. & Tateli Satu & 175 \\
8. & Tateli Dua & 356 \\
9. & Tateli Tiga & 170 \\
10. & Koha Timur & 800 \\
11. & Koha Barat & 774 \\
12. & Koha Selatan & 2510 \\
\hline \multicolumn{2}{c}{ Jumlah }
\end{tabular}

Sumber Data: BPS, 2015

Tabel 1 menujukkan bahwa luas wilayah menurut Desa adalah Koha seluas 2950 (Ha), dan luas wilayah terendah adalah Kalasey Satu seluas 125 (Ha).

\section{Jumlah Penduduk Menurut Desa dan Jenis Kelamin}

Persentase jumlah penduduk menurut desa di Kecamatan Mandolang terlihat pada Tabel 2, dimana jumlah penduduk menurut desa adalah Kalasey Satu dan desa yang terkecil persentase jumlah penduduknya adalah Agotey.

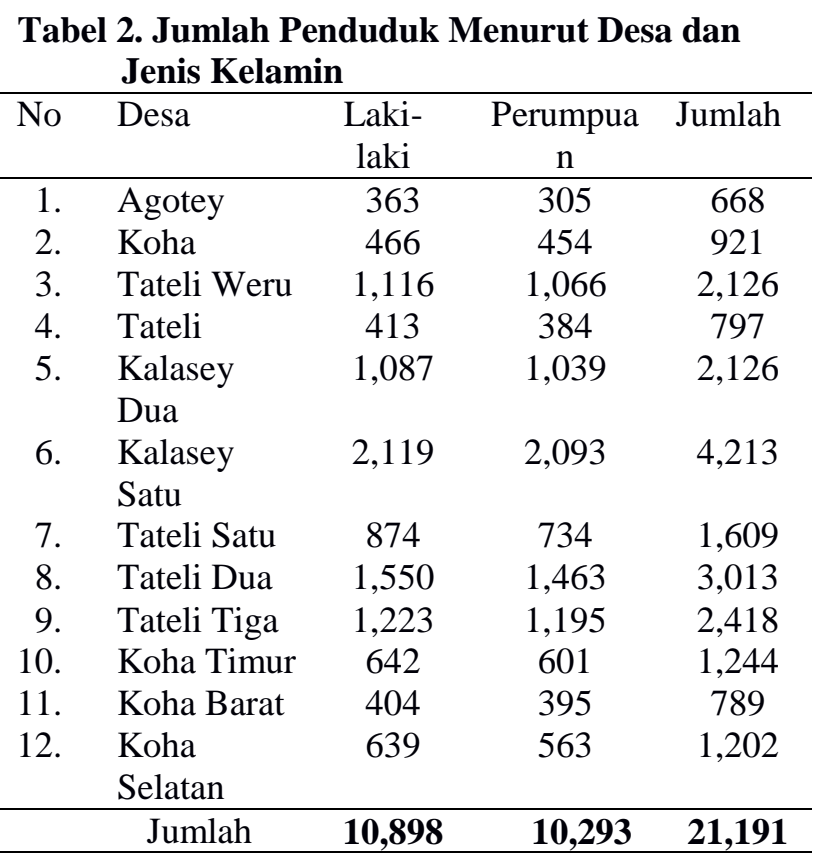

Sumber Data: BPS, 2015
Tabel 2 menunjukkan jumlah penduduk menurut desa dan jenis kelamin, dan untuk perbandingan antara laki-laki dan perempuan. Berdasarkan Tabel 2 diketahui jumlah penduduk laki-laki adalah 10,898 jiwa dan penduduk perempuan 10,293 jiwa maka sebesar 21,191. Artinya pada tahun 2013 setiap 100 penduduk perempuan terdapat 21,191 penduduk laki-laki. Desa Kalasey Satu memiliki angka perbandingan tertinggi yaitu sebesar 4,213 dan desa terendah adalah Agotey yaitu sebesar 668 .

\section{Jumlah Kepala Keluarga Menurut Desa dan Pendidikan Formal}

Persentase jumlah kepala keluarga menurut desa dan pendidikan terlihat pada Tabel 3 , dimana jumlah kepala keluarga menurut desa adalah Kalasey Satu.

Tabel 3. Kepala Keluarga Menurut Desa dan Pendidikan Formal yang Ditamatkan.

\begin{tabular}{lccc}
\hline Desa & $\begin{array}{c}\text { Tidak } \\
\text { Tamat SD }\end{array}$ & $\begin{array}{c}\text { SD/SM } \\
\mathrm{P}\end{array}$ & SLTA \\
\hline Tateli Dua & 80 & 150 & 320 \\
Tateli Tiga & 57 & 143 & 200 \\
Koha Barat & 35 & 70 & 64 \\
Koha Selatan & 35 & 80 & 62 \\
Koha Timur & 40 & 70 & 61 \\
Tateli Weru & 130 & 250 & 150 \\
Agotey & 6 & 75 & 102 \\
Tateli & 40 & 70 & 107 \\
Kalasey Dua & 27 & 235 & 157 \\
Kalasey Satu & 170 & 251 & 394 \\
Koha & 50 & 50 & 93 \\
Koha Satu & 40 & 80 & 230 \\
\hline \multicolumn{1}{c}{ Jumlah } & $\mathbf{7 1 0}$ & $\mathbf{1 5 2 4}$ & $\mathbf{1 . 9 4 0}$ \\
\hline Sum
\end{tabular}

Sumber: BPS, 2015

Tabel 4 menunjukan bahwa kepala keluarga menurut desa dan pendidikan tinggi yang ditamatkan, dimana kepala keluarga menurut desa adalah Kalasey Satu jumlah sebesar 170 SD, SD/SMP 251, dan SLTA 394.

\section{Jumlah Kepala Keluarga Menurut Desa}

Persentase jumlah kepala keluarga menurut desa di Kecamatan Mandolang terlihat pada Tabel 4, dimana jumlah kepala keluarga menurut desa adalah Kalasey Satu dan desa yang terkecil persentase jumlah kepala keluarga adalah Koha Barat. 
Tabel 4. Jumlah Kepala Keluarga Menurut Desa dan Status Perkawinan.

\begin{tabular}{rlrrc}
\hline & Desa & Kawin & $\begin{array}{c}\text { Janda/ } \\
\text { Duda }\end{array}$ & Jumlah \\
\hline 1. & Tateli Dua & 500 & 150 & 700 \\
2. & Tateli Tiga & 310 & 200 & 510 \\
3. & Koha Barat & 169 & 50 & 219 \\
4. & Koha Selatan & 227 & 80 & 307 \\
5. & Koha Timur & 241 & 70 & 311 \\
6. & Tateli Weru & 460 & 100 & 560 \\
7. & Agotey & 180 & 26 & 206 \\
8. & Tateli & 282 & 65 & 347 \\
9. & Kalasey Dua & 330 & 129 & 459 \\
10. & Kalasey Satu & 820 & 178 & 998 \\
11. & Koha & 198 & 45 & 243 \\
12. & Tateli Satu & 270 & 34 & 394 \\
\hline & Jumlah/Total & 4037 & 1127 & 5164 \\
\hline
\end{tabular}

Sumber: BPS, 2015.

Tabel 4 menunjukkan jumlah kepala keluarga menurut desa dan status perkawinan, dan untuk perbandingan antara kawin dan janda/tuda. Berdasarkan tabel di atas diketahui jumlah kepala keluarga kawin adalah 820 jiwa dan jumlah janda/duda 178 jiwa maka sebesar 998, dan desa terendah adalah Koha Barat yaitu sebesar 219.

\section{Karakteristik Responden}

Karakteristik responden di daerah penelitian ini diperoleh berdasarkan survei/wawancara yang dilakukan kepada 5 responden yang melakukan alih fungsi lahan pertanian.Karakteristik umum tersebut terdiri dari tingkat usia, tingkat pendidikan, pekerjaan responden, jumlah tanggungan kelurga, luas lahan yang dimiliki.

\section{Tingkat Umur}

Tingkat usia menggambarkan perilaku kemampuan dalam berkerja. Semakin tua seseorang menggambarkan kemampuan tubuhnya semakin lemah dalam bekerja. Keadaan umur responden yang melakukan alih fungsi lahan pertanian dalam penelitian ini dapat dilihat pada Tabel 5 .

Tabel 5. Jumlah Responden Berdasarkan Tingkat Umur

\begin{tabular}{cccc}
\hline No & $\begin{array}{c}\text { Umur } \\
\text { (tahun) }\end{array}$ & $\begin{array}{c}\text { Jumlah Responden } \\
\text { (orang) }\end{array}$ & $\begin{array}{c}\text { Persentase } \\
(\%)\end{array}$ \\
\hline 1. & $24-30$ & 4 & 13,3 \\
2. & $32-36$ & 3 & 10 \\
3. & $40-42$ & 4 & 13,3 \\
4. & $47-49$ & 5 & 16,8 \\
5. & $50-55$ & 10 & 33,3 \\
6. & $62-76$ & 4 & 13,3 \\
\hline & Jumlah & 30 & 100
\end{tabular}

Sumber : Diolah dari data primer, 2016
Tabel 5 menunjukkan bahwa jumlah responden interval umur 50 - 55 tahun 33,3 persen, dan selanjutnya pada interval umur 47 - 49 tahun 16,6 persen, dan yang paling sedikit responden yang berada pada interval umur 32 3910 persen. Dan sebagian besar responden yang melakukan alih fungsi lahan adalah pemilik lahan pada sebaran umur 47 - 49 tahun sebesar 16,6 persen dan $62-76$ tahun sebesar 13,3 persen.

\section{Tingkat Pendidikan Responden}

Tingkat pendidikan menentukan cara berpikir seseorang dalam pengambilan keputusan. Semakin tinggi tingkat pendidikan seseorang maka akan menentukan sikap dan mempengaruhi pengambilan keputusan seseorang. Begitu juga pada pemilik lahan, tingkat pendidikan akan mempengaruhi pemilik lahan untuk mengalih fungsikan lahan pertanian.

Tabel 6. Jumlah Responden menurut Tingkat Pendidikan Formal

\begin{tabular}{lccc}
\hline No & $\begin{array}{c}\text { Tingkat } \\
\text { Pendidikan }\end{array}$ & $\begin{array}{c}\text { Jumlah Responden } \\
\text { (orang) }\end{array}$ & $\begin{array}{c}\text { Persentase } \\
(\%)\end{array}$ \\
\hline 1. & SD & 1 & 3,3 \\
2. & SMP & 7 & 23,3 \\
4. & SMA/SLTA & 19 & 63,3 \\
5. & D3 & 3 & 10 \\
\hline Jumlah & 30 & 100 \\
\hline \multicolumn{2}{l}{ Sumber : dari data primer, 2016}
\end{tabular}

Tabel 6 menunjukkan tingkat pendidikan yang dimiliki responden. Dan tingkat pendidikan responden yang paling banyak yaitu SMA sebanyak 17 responden ( 3,3 persen), sedangkan tingkat SMP sebanyak 7 responden (23,3 persen), tingkat D3 sebanyak 3 responden 10 persen, tingkat SD atau dulu disebut SR (sekolah rakyat) hanya 1 responden dan tingkat pendidikan SMK dan SLPA paling sedikit yaitu 1 responden (3,3 persen).

\section{Pekerjaan Responden}

Jenis pekerjaan sangat mempengaruhi sikap seseorang terhadap lahannya. Karena ketika seseorang sudah menemukan pekerjaan yang tepat dengan tingkat pendapatan yang cukup atau lebih untuk memenuhi kebutuhan keluarga, maka akan fokus dengan pekerjaannya dan hal ini mempengaruhi seseorang untuk mengalihfungsikan lahan pertaniannya. Tabel 7 menunjukkan jenis pekerjaan responden pemilik lahan tidur yang dijadikan sampel dalam penelitian ini. 
Tabel 7. Jumlah Responden menurut Jenis Pekerjaan

\begin{tabular}{llcc}
\hline No & Jenis Pekerjaan & $\begin{array}{c}\text { Jumlah } \\
\text { Responden } \\
\text { (orang) }\end{array}$ & $\begin{array}{c}\text { Persentase } \\
(\%)\end{array}$ \\
\hline 1. & PNS & 11 & 36,6 \\
2. & Swasta & 10 & 33,3 \\
3. & IRT & 8 & 26,6 \\
4. & Pengusaha & 1 & 3,3 \\
& Ternak & \\
\hline Jumlah & 30 & 100 \\
\hline \multicolumn{2}{l}{ Sumber : Diolah dari data primer, 2016 }
\end{tabular}

Tabel 7 menunjukkan bahwa dalam penelitian ini terdapat 4 kategori jenis pekerjaan dari responden, yaitu Pengawai Negeri Sipil, swasta, pengusaha ternak, dan ibu rumah tangga. Kategori pengawai negeri sipil merupakan jenis pekerjaan dari responden yaitu masing-masing sebanyak 11 responden (36,6 persen). Sedangkan jenis pekerjaan yang lain seperti swasta sebanyak 10 responden (33,3 persen), dan ibu rumah tangga sebanyak 8 responden (26,6 persen), dan pengusaha ternak hanya 1 responden (3,3 persen). Hal ini menunjukkan bahwa sebagian besar yang mengalihfungsikan lahan pertanian yaitu yang mempunyai jenis pekerjaan sebagai swasta, pengusaha ternak, dan ibu rumah tangga.

\section{Jumlah Responden Menurut Tanggungan Keluarga}

Jumlah anggota kelurga yang terhitung dalam jumlah tanggungan umumnya membantu kelurga dalam hal penyediaan tenaga kerja dalam keluarga dengan sendirinya akan mengurangi masuknya tenaga kerja dari luar keluarga. Jumlah tanggungan keluarga responden yang mengalihfungsikan lahan pertanian disajikan pada Tabel 8 .

\begin{tabular}{lccc} 
Tabel & 8. & $\begin{array}{c}\text { Jumlah } \\
\text { Tanggungan Keluarga }\end{array}$ & $\begin{array}{c}\text { Responden } \\
\text { Menurut }\end{array}$ \\
\hline No & $\begin{array}{c}\text { Jumlah } \\
\text { Tanggungan } \\
\text { (orang) }\end{array}$ & $\begin{array}{c}\text { Jumlah } \\
\text { Responden } \\
\text { (orang) }\end{array}$ & $\begin{array}{c}\text { Persentase } \\
(\%)\end{array}$ \\
\hline 1. & 1 & 2 & 6,6 \\
2. & 2 & 13 & 43,3 \\
3. & 3 & 14 & 46,6 \\
4. & 4 & 1 & 3,3 \\
\hline Jumlah & & 30 & 100 \\
\hline
\end{tabular}

Sumber : Diolah dari data primer, 2016

Tabel 8 menunjukkan jumlah tanggungan responden yaitu 3 orang tanggungan sebanyak 14 responden (46,6 persen), dan 2 orang tanggungan sebanyak 13 responden (43,3 persen), dan 1 orang tanggungan hanya 2 responden (6,6 persen).
Sedangkan jumlah tanggungan 4 orang paling sedikit hanya 1 responden (3,3 persen).

\section{Jumlah Luas Lahan Responden}

Luas lahan yang dimiliki responden yang melakukan alih fungsi lahan bervariasi. Kisaran luas lahan yang mereka miliki dari $300 \mathrm{~m}^{2}, 700$ $\mathrm{m}^{2}$, dan $1.200 \mathrm{~m}^{2}$ sampai dengan lebih dari 3.000 $\mathrm{m}^{2}$. Namun, hampir seluruh luas lahan yang mereka miliki dialihfungsikan.

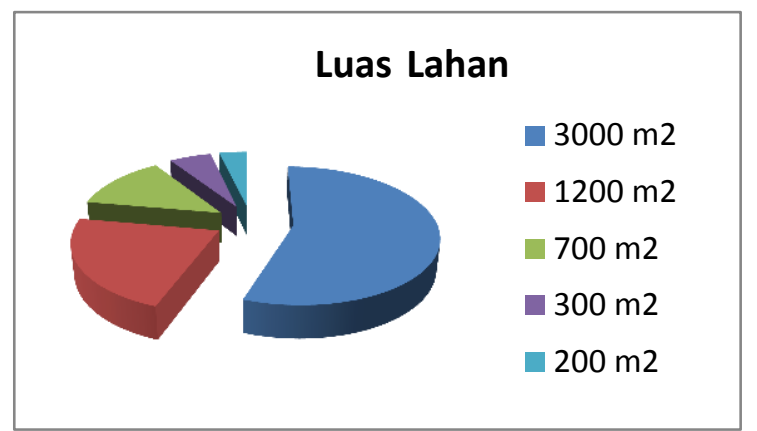

Gambar 1. Luas Lahan Responden (diolah)

Berdasarkan Gambar 1 luas lahan yang dimliki responden yaitu, memiliki lahan dengan luas $200 \mathrm{~m}^{2}, 300 \mathrm{~m}^{2}, 700 \mathrm{~m}^{2}$, dan lebih dari $1.200 \mathrm{~m}^{2}-$ $3.000 \mathrm{~m}^{2}$ lahan yang dimiliki responden.

\section{Alih Fungsi di Tingkat Pemilik Lahan}

Sebanyak tiga puluh responden dalam penelitian ini adalah pemilik lahan yang sebelumnya merupakan petani dan telah mengalihfungsikan lahannya ke non-pertanian. Sebelumnya, pemilik lahan tersebutbergantung hidup sepenuhnya pada sektor pertanian. Mereka mengolah bahwa bertani merupakan mata pencaharian pokok. Adanya alih fungsi lahan yang terjad iakan berpengaruh terhadap kehidupan mereka. Pola alih fungsi lahan yang terjadi di tingkat pemilik lahan menurut luas lahan bahwa seluruh pemilik lahan responden mengalihfungsikan lahan yang dimilikinya secara keseluruhan. Besaran lahan yang mengalami alih fungsi dapat dilihat pada Tabel 9.

Tabel 9 . Luas Lahan yang Mengalami Alih Fungsi

\begin{tabular}{lccc}
\hline No & $\begin{array}{c}\text { Luas Lahan }( \\
\left.\mathbf{M}^{2}\right)\end{array}$ & $\begin{array}{c}\text { Jumlah } \\
\text { Responden } \\
\text { (orang) }\end{array}$ & $\begin{array}{c}\text { Persentase } \\
(\%)\end{array}$ \\
\hline 1. & $200-800$ & 6 & 20,0 \\
2. & $801-1400$ & 16 & 53,3 \\
3. & $1401-2000$ & 2 & 6,7 \\
4. & $2001-2600$ & 4 & 13,3 \\
5. & 3000 & 2 & 6,7 \\
\hline Jumlah & 30 & 100,00 \\
\hline
\end{tabular}

Sumber : Diolah dari data primer, 2016 
Tabel 9 menunjukkan luas lahan yang mengalami alih fungsi responden yang sebanyak 16 responden (53,3 persen), dan 6 responden (20,0 persen), dan 4 responden (13,3 persen). Sedangkan jumlah mengalihfungsikan lahan paling sedikit hanya 2 responden $(6,7$ persen).

Hal ini mengindikasikan adanya perubahan besar terhadap suatu kawasan dimana sebelumnya kawasan ini merupakan lahan kosong menjadi kawasan terbangun. Seharusnya ini perlu mendapatkan perhatian lebih serius dari pemerintah akan adanya dampak negatif yang akan timbul. Pola alih fungsi lahan tersebut mengakibatkan penurunan luas lahan secara besar besaran yang berdampak pada penurunan luas kepemilikan lahan. Nantinya, hal ini akan mengurangi ketersediaan lahan yang akan mempengaruhi mata pencaharian masyarakat dimana lahan merupakan sumber utama mata pencaharian masyarakat. Lebih lanjut lagi, keadaan ini akan mempengaruhi kesempatan kerja di sektor pertanian dimana akan terjadi pergeseran tenaga kerja dari sektor pertanian ke non pertanian. Furi (2007) menjelaskan bahwa alih fungsi lahan yang terjadi mengubah status kepemilikan lahan dan penguasaan lahan. Perubahan dalam penguasaan lahan dipedesaan membawa implikasi bagi perubahan pendapatan dan kesempatan kerja masyarakat yang menjadi indikator kesejahteraan masyarakat.

Pemilik lahan yang telah menjual seluruh lahannya banyak yang berubah mencari pekerjaan lain. Hal tersebut disebabkan karena mereka kurang memanfaatkan hasil penjualan lahannya. Selain itu keterampilan yang mereka peroleh karena pendidikan mereka yang terbilang baik sehingga bagi mereka untuk beralih profesi ke sektor lain. Penerimaan dari hasil penjualan lahan yang mereka peroleh cukup bervariasi. Perbedaan tersebut disebabkan karena adanya perbedaan luas lahan yang dijual dan harga lahan. Luas lahan yang beralih fungsi rata-rata $200 \mathrm{~m}^{2}, 300 \mathrm{~m}^{2}, 700$ $\mathrm{m}^{2}, 1200 \mathrm{~m}^{2}$. setiap pemilik lahan. Tahun penjualan lahan yang dilakukan oleh pemilik lahan berbeda-beda. Penjualan lahan tersebut terjadi sejak tahun 2000-2011. Harga lahan yang diterima pemilik juga berbeda-beda tergantung letak lahan yang dijual. Harga lahan rata-rata yang diterima oleh pemilik lahan berdasakan hasil penelitian di Desa Kalasey Satu,mulai dari Rp 25.000,00 per $\mathrm{m}^{2}$ pada tahun 2000 hingga $\mathrm{Rp}$ $90.000,00$ per $\mathrm{m}^{2}$ pada tahun 2011.

\section{Sikap pemilk lahan Terhadap Alih Fungsi Lahan}

Sikap pemilik terhadap alih fungsi lahan adalah penilaian positif atau negatif yang diberikan oleh pemilik lahan terhadap adanya alih fungsi lahan yang ada di Desa Kalasey Satu. Sikap ini ditunjukkan oleh penilaian pemilik lahan terhadap aspek-aspek alih fungsi lahan yang meliputi faktor penyebab alih fungsi lahan, pola alih fungsi lahan dan pemanfaatan lahan yang dialihfungsikan, serta dampak alih fungsi lahan terhadap kehidupan pemilik lahan. Sikap pemilik lahan terhadap alih fungsi lahan dibagi menjadi lima kategori yaitu sangat setuju, setuju, tidak setuju, sangat tidak setuju, dan ragu-ragu. Pernyataan yang diberikan merupakan pernyataan yang menunjukkan penilaian positif terhadap alih fungsi lahan. Berdasarkan penilaian dari pernyataan yang diberikan, skor terendah dimiliki oleh responden (pemilik lahan) yang menunjukkan sikap sangat setuju terhadap alih fungsi lahan. Sementara skor tertinggi dimiliki tabel yang menunjukkan sikap responden (pemilik lahan) terhadap alih fungsi lahan oleh responden yang menunjukkan sikap sangat tidak setuju terhadap adanya alih fungsi lahan. Skor ini diperoleh melalui jawaban responden saat mengisi kuesioner penelitian. Berikut ini adalah tabel yang menunjukkan sikap responden (pemilik lahan) terhadap alih fungsi lahan.

Tabel 10. Jumlah Responden Menurut Sikap Pemilk Lahan Terhadap Alih Fungsi Lahan

\begin{tabular}{lcc}
\hline Kategori sikap & $\begin{array}{c}\text { Jumlah responden } \\
\text { (Orang) }\end{array}$ & $\begin{array}{c}\text { Persentse } \\
(\%)\end{array}$ \\
\hline Sangat Setuju & 3 & 10,0 \\
Setuju & 3 & 10,0 \\
Ragu-ragu & 4 & 13,3 \\
Tidak Setuju & 5 & 16,6 \\
Sangat Tidak & 14 & 46,6 \\
Setuju & & 100.0 \\
\hline Total & 30 &
\end{tabular}

Sumber : Diolah dari data primer, 2016

Berdasarkan Tabel 10, sebanyak 14 responden (pemilik lahan) memiliki sikap tidak setuju terhadap alih fungsi lahan. Posisi kedua dengan selisih yang cukup jauh dimiliki oleh pemilik lahan yang sangat tidak setuju terhadap alih fungsi lahan. Sementara pemilik lahan yang menilai setuju bahkan sangat setuju terhadap alih fungsi lahan berturut-turut berjumlah 3 dan 3 orang. Tabel tersebut menunjukkan bahwa sebagian besar masyarakat yang terwakili oleh 30 
responden memiliki sikap tidak setuju terhadap alih fungsi lahan. Alih fungsi lahan di lokasi penelitian sebagian besar dimanfaatkan untuk bagunan rumah dan lain-lain. Berdasarkan hasil wawancara, sekitar $16,6 \%$ responden menyatakan tidak setuju terhadap alih fungsi lahan menjadi perumahan, dan bagunan lainnya tetapi menyatakan setuju terhadap alih fungsi lahan menjadi bagunan lain atau industri yang dapat menyerap tenaga kerja. Sementara 16,6 persen menyatakan tidak setuju terhadap alih fungsi lahan menjadi perumahan kecuali untuk membangun rumah pribadi. Data tersebut menunjukkan bahwa sebesar $10 \%$ menunjukkan sikap pemilik lahan setuju terhadap alih fungsi lahan, namun tergantung pada pemanfaatan lahan yang dialihfungsikan.

Sikap pemilik lahan terhadap alih fungsi lahan lahan diduga memiliki hubungan dengan karakteristik individu responden. Karakteristik tersebut antara lain jenis kelamin, usia, tingkat pendidikan, status pekerjaan pemilik lahan, jumlah tanggungan dalam keluarga, tingkat pendapatan, dan penguasaan dan luas lahan oleh pemilik lahan. Jenis kelamin dibedakan menjadi perempuan dan lakilaki. Sikap pemilik lahan terhadap alih fungsi lahan berdasarkan jenis kelamin dapat dilihat sebagai berikut.

Tabel 11 menunjukkan bahwa sekitar $3,3 \%$ dari $8,4 \%$ responden berusia muda cenderung memiliki sikap negatif terhadap alih fungsi lahan. Hal ini ditunjukkan dengan pernyataan responden berusia muda yang menyatakan tidak setuju sebanyak $0,0 \%$ dan sangat tidak setuju sebanyak $3,3 \%$. Sikap negatif terhadap alih fungsi lahan juga ditunjukkan oleh sekitar 53,3\% dari 56,6\% responden berusia sedang. Sikap negatif ditunjukkan dengan pernyataan responden berusia sedang yang menyatakan tidak setuju sebanyak 5,0\% dan sangat tidak setuju sebanyak $26,6 \%$. Sikap yang sama ditunjukkan juga oleh sekitar $20,7 \%$ dari $26,6 \%$ responden berusia tua. Sikap negatif ditunjukkan dengan pernyataan responden berusia tua yang menyatakan tidak setuju sebanyak 3,3\% dan sangat tidak setuju sebanyak $3,3 \%$. Tabel tersebut menyimpulkan bahwa baik responden berusia muda, sedang, maupun tua memiliki sikap negatif terhadap alih fungsi lahan.

Tingkat pendidikan responden digolongkan menjadi empat kategori yaitu rendah, sedang, dan tinggi. Kategori rendah dimiliki oleh responden dengan tingkat pendidikan SD-SMP atau sederajat, kategori sedang dimiliki oleh responden dengan tingkat pendidikan SMA/SLTA atau sederajat, dan tingkat pendidikan tinggi dimiliki oleh responden dengan tingkat pendidikan D3. Sikap pemilik lahan terhadap alih fungsi lahan berdasarkan tingkat pendidikan dapat dilihat sebagai berikut.

Tabel 12 menunjukkan bahwa sekitar $36,6 \%$ responden berpendidikan (SD-SMP) cenderung memiliki sikap negatif terhadap alih fungsi lahan. Hal ini ditunjukkan dengan pernyataan responden berpendidikan yang menyatakan tidak setuju sebanyak 5,0\% dan sangat tidak setuju sebanyak 13,3\%. Sikap negatif terhadap alih fungsi lahan juga ditunjukkan oleh sekitar 3,0\% responden berpendidikan (SMA). Sikap negatif ditunjukkan dengan pernyataan responden berpendidikan yang menyatakan tidak setuju sebanyak 1,3\% dan sangat tidak setuju $16,6 \%$. Sikap yang sama ditunjukkan juga oleh seluruh responden berpendidikan (D3). Sikap negatif ditunjukkan dengan pernyataan responden berpendidikan yang menyatakan tidak setuju sebanyak $5,0 \%$ dan sangat tidak setuju sebanyak 16,6\%. Responden berpendidikan tinggi tidak ada satu pun yang memiliki sikap negatif terhadap alih fungsi lahan. Tabel tersebut menyimpulkan bahwa baik responden berpendidikan rendah, sedang, maupun tinggi memiliki sikap negatif terhadap alih fungsi lahan.

Status pekerjaan adalah status yang dipilih oleh responden dalam bekerja sebagai PNS, Swasta maupun beternak. Status ini dikategorikan menjadi 3, yaitu status pekerjaan PNS, Swasta, Beternak sebagai pekerjaan utama dan sampingan. Status ini sulit dilihat ketika responden memiliki pekerjaan lain. Oleh karena itu, perlu diketahui berdasarkan pertanyaan yang diberikan mengenai status mana yang dipilih oleh responden. Berikut ini disajikan tabel untuk mengetahui sikap pemilik lahan terhadap alih fungsi lahan berdasarkan status pekerjaan.

Tabel 14 menunjukkan bahwa sekitar $75,3 \%$ dari 83,3\% responden berstatus pekerjaan PNS sebagai pekerjaan utama cenderung memiliki sikap pemilik lahan negatif terhadap alih fungsi lahan. Hal ini ditunjukkan dengan pernyataan responden berstatus pekerjaan PNS, Swatsa sebagai pekerjaan utama yang menyatakan tidak setuju sebanyak $0,0 \%$ 
dan sangat tidak setuju sebanyak 20\%. Sikap negatif terhadap alih fungsi lahan juga ditunjukkan oleh sekitar $10,6 \%$ dari $16,6 \%$ responden berstatus pekerjaan sebagai pekerjaan sampingan. Sikap negatif ditunjukkan dengan pernyataan responden berstatus pekerjaan sebagai pekerjaan sampingan yang menyatakan tidak setuju sebanyak 3,3\% dan sangat tidak setuju sebanyak 26,6\%. Tabel tersebut menyimpulkan bahwa baik responden berstatus pekerjaan PNS, Swasta sebagai pekerjaan utama maupun ada pekerjaan sampingan memiliki sikap pemilik lahan negatif terhadap alih fungsi lahan.

Jumlah tanggungan keluarga adalah jumlah orang dalam keluarga yang masih ditanggung biaya hidupnya oleh responden. Penggolongan jumlah tanggungan dalam keluarga dilakukan berdasarkan sebaran data di lapangan. Jumlah tanggungan dalam keluarga digolongkan menjadi sedikit, sedang, dan banyak. Kategori jumlah tanggungan dalam keluarga yang tergolong sedikit dimiliki oleh responden yang memiliki tanggungan < 2 orang, jumlah tanggungan sedang antara $3-4$ orang, dan jumlah tanggungan banyak dimiliki oleh responden yang memiliki tanggungan $>4$ orang. Sikap pemilik lahan terhadap alih fungsi lahan berdasarkan jumlah tanggungan dalam keluarga dapat dilihat pada tabel berikut.

Data pada tabel 14 menunjukkan bahwa sekitar $10,7 \%$ dari $20 \%$ responden yang memiliki jumlah tanggungan dalam keluarga tergolong sedikit cenderung memiliki sikap negatif terhadap alih fungsi lahan. Hal ini ditunjukkan dengan pernyataan responden yang memiliki jumlah tanggungan dalam keluarga tergolong sedikit yang menyatakan tidak setuju sebanyak 50\% dan sangat tidak setuju sebanyak 3,3\%. Sikap negatif terhadap alih fungsi lahan juga ditunjukkan oleh sekitar $33,3 \%$ dari $63,3 \%$ responden yang memiliki jumlah tanggungan dalam keluarga tergolong sedang. Sikap negatif ditunjukkan dengan pernyataan responden yang memiliki jumlah tanggungan dalam keluarga tergolong sedang yang menyatakan tidak setuju sebanyak $33,3 \%$ dan sangat tidak setuju sebanyak $20 \%$. Sikap yang sama ditunjukkan juga oleh seluruh responden yang memiliki jumlah tanggungan dalam keluarga tergolong banyak. Sikap negatif ditunjukkan dengan pernyataan responden yang memiliki jumlah tanggungan dalam keluarga tergolong banyak yang menyatakan tidak setuju sebanyak 3,3\% dan sangat tidak setuju sebanyak $3,3 \%$. Responden yang memiliki jumlah tanggungan dalam keluarga tergolong banyak tidak ada satu pun yang memiliki sikap negatif terhadap konversi lahan pertanian. Tabel tersebut menyimpulkan bahwa baik responden yang memiliki jumlah tanggungan dalam keluarga tergolong sedikit, sedang, maupun banyak memiliki sikap negatif terhadap alih fungsi lahan.

Karakteristik individu yang terakhir adalah penguasaan dan luas lahan oleh pemilik lahan. Penguasaan dan luas lahan oleh pemilik lahan menjelaskan mengenai kepemilikan dan luas lahan yang dapat diakses oleh pemilik lahan. Penguasaan dan luas lahan oleh pemiliki lahan dikategorikan menjadi pemilik lahan berlahan luas, pemilik lahan berlahan sempit, dan pemilik lahan. Pemilik lahan dikatakan berlahan luas jika pemilik lahan tersebut memiliki lahan dengan luas $<3000 \mathrm{~m}^{2}$. Pemilik lahan dikatakan berlahan sempit jika petani tersebut memiliki lahan dengan luas $<300 \mathrm{~m}^{2}$. Berikut ini adalah sikap pemilik lahan terhadap alih fungsi lahan berdasarkan luas dan penguasaan lahan oleh pemilik lahan.

Data pada Tabel 16 menunjukkan bahwa baik pemilk lahan berlahan luas, pemilik lahan berlahan sempit, cenderung memiliki sikap negatif terhadap alih fungsi lahan. Hal ini ditunjukkan dengan persentase untuk pernyataan tidak setuju sebanyak 23,3\% untuk pemilik lahan berlahan luas, 33,3\% untuk pemilik lahan berlahan sempit, dari total pernyataan tidak setuju sebanyak $56,6 \%$. Sementara pernyataan sangat tidak setuju sebanyak 5,0\% untuk pemilik lahan berlahan luas, $16,6 \%$ untuk pemilik lahan berlahan sempit, dan $6,6 \%$, dari total pernyataan sangat tidak setuju sebanyak $26,6 \%$.

Berdasarkan tabel yang telah disajikan mengenai sikap pemilik lahan terhadap alih fungsi lahan berdasarkan karakteristik individu (jenis kelamin, usia, tingkat pendidikan, status pekerjaan bertani, jumlah tanggungan dalam keluarga, serta luas dan penguasaan lahan oleh pemilik lahan) dapat disimpulkan bahwa $80 \%$ pemilik lahan (56,6\% tidak setuju dan $26,6 \%$ sangat tidak setuju) memiliki sikap negatif terhadap alih fungsi lahan. Sikap ini menggambarkan bahwa alih fungsi lahan yang dilakukan bukan hal yang diinginkan oleh pemilik lahan maupun masyarakat setempat pada umumnya. 
Tabel 11 . Sikap Pemilik Lahan Terhadap Alih Fungi Lahan Berdasarkan Usia

\begin{tabular}{|c|c|c|c|c|c|c|}
\hline \multirow[b]{2}{*}{$\begin{array}{c}\text { Kategori } \\
\text { usia }\end{array}$} & \multicolumn{5}{|c|}{ Sikap Pemilik Lahan } & \multirow[b]{2}{*}{ Total } \\
\hline & Sangat setuju & Setuju & Ragu-ragu & Tidak setuju & Sangat tidak setuju & \\
\hline$(<36$ thn $)$ & $1(1,7 \%)$ & $2(3,3 \%)$ & $0(0,0 \%)$ & $0(0,0 \%)$ & $2(3,3 \%)$ & $5(8,4 \%)$ \\
\hline (40-49 thn) & $2(3,3 \%)$ & $2(3,3 \%)$ & $2(3,3 \%)$ & $3(5,0 \%)$ & $8(26,6 \%)$ & $17(56,6 \%)$ \\
\hline (62-79 thn) & $0(0,0 \%)$ & $2(3,3 \%)$ & $2(3,3 \%)$ & $2(3,3 \%)$ & $2(3,3 \%)$ & $8(26,6 \%)$ \\
\hline Total & $3(5,0 \%)$ & $6(20 \%)$ & $4(13,3 \%)$ & $5(8,4 \%)$ & $12(40 \%)$ & $30(100,0 \%)$ \\
\hline
\end{tabular}

Sumber : Diolah dari data primer, 2016

Tabel 12. Sikap Pemilik Lahan Terhadap Alih Fungi Lahan Berdasarkan Tingakat Pendidikan

Sikap Pemilik Lahan

\begin{tabular}{lcccccc} 
Tingkat pendidikan & Sangat setuju & Setuju & Ragu-ragu & Tidak setuju & Sangat tidak setuju & Total \\
\cline { 2 - 5 } (SD-SMP) & $0(0,0 \%)$ & $2(3,3 \%)$ & $2(3,3 \%)$ & $3(5,0 \%)$ & $4(13,3 \%)$ & $11(36,6, \%)$ \\
(SMA) & $0(0,0 \%)$ & $3(5,0 \%)$ & $0(0,0 \%)$ & $1(1,3 \%)$ & $5(16,6 \%)$ & $9(30 \%)$ \\
(D3) & $0(0,0 \%)$ & $2(3,3 \%)$ & $0(0,0 \%)$ & $3(5,0 \%)$ & $5(16,6 \%)$ & $10(33,3 \%)$ \\
Total & $1(1,3 \%)$ & $7(23,3 \%)$ & $2(3,3 \%)$ & $6(20,0 \%)$ & $15(50 \%)$ & $30(100,0 \%)$ \\
\hline
\end{tabular}

Sumber : Diolah dari data primer, 2016

Tabel 13. Sikap Pemilik Lahan Terhadap Alih Fungi Lahan Berdasarkan Status Pekerjaan

\begin{tabular}{lcccccc}
\hline & \multicolumn{5}{c}{ Sikap Pemilik Lahan } & Total \\
\cline { 2 - 6 } Status pekerjaan & Sangat setuju & Setuju & Ragu-ragu & Tidak setuju & Sangat tidak setuju & $25(83,3, \%)$ \\
Utama & $9(30 \%)$ & $10(33,3 \%)$ & $0(0,0 \%)$ & $0(0,0 \%)$ & $6(20 \%)$ & $5(16,6 \%)$ \\
Sampingan & $0(0,0 \%)$ & $1(1,3 \%)$ & $0(0,0 \%)$ & $2(3,3 \%)$ & $2(3,3 \%)$ & $30(100,0 \%)$ \\
Total & $9(30 \%)$ & $11(36,6 \%)$ & $0(0,0 \%)$ & $2(3,3 \%)$ & $8(26,6 \%)$ & 3 \\
\hline
\end{tabular}

Sumber : Diolah dari data primer, 2016

Tabel 14. Sikap Pemilik Lahan Terhadap Alih Fungi Lahan Berdasarkan Jumlah Tanggungan Dalam Keluarga

\begin{tabular}{ccccccc}
\hline \multicolumn{1}{c}{$\begin{array}{c}\text { Jumlah Tanggungan } \\
\text { dalam keluarga }\end{array}$} & Sangat setuju & Setuju & Ragu-ragu & Tidak setuju & Sangat tidak setuju & Total \\
\hline $\begin{array}{c}(<2 \text { orang) } \\
\text { (2-3 orang) }\end{array}$ & $0(0,0 \%)$ & $1(1,3 \%)$ & $0(0,0 \%)$ & $3(5,0 \%)$ & $2(3,3 \%)$ & $6(20 \%)$ \\
(4 orang) & $1(1,3 \%)$ & $2(3,3 \%)$ & $0(0,0 \%)$ & $10(33, \%)$ & $6(20 \%)$ & $19(63,3 \%)$ \\
Total & $0(0,0)$ & $1(1,3 \%)$ & $0(0,0 \%)$ & $2(3,3 \%)$ & $2(3,3 \%)$ & $5(16,6 \%)$ \\
\hline
\end{tabular}

Sumber : Diolah dari data primer, 2016

Tabel 15. Sikap Pemilik Lahan Terhadap Alih Fungi Lahan Berdasarkan Luas Lahan Dan Penguasaan Lahan Oleh Pemilik Lahan

\begin{tabular}{|c|c|c|c|c|c|c|}
\hline $\begin{array}{c}\text { Kategori luas dan } \\
\text { penguasaan }\end{array}$ & & & Sikap Pem & Lahan & & \\
\hline $\begin{array}{l}\text { lahan oleh pemilik } \\
\text { lahan }\end{array}$ & $\begin{array}{c}\text { Sangat } \\
\text { setuju }\end{array}$ & Setuju & Ragu-ragu & Tidak setuju & $\begin{array}{c}\text { Sangat tidak } \\
\text { setuju }\end{array}$ & Total \\
\hline$\left(<3000 \mathrm{~m}^{2}\right)$ & $0(0,0 \%)$ & $1(1,3 \%)$ & $0(0,0 \%)$ & $7(23,3 \%)$ & $3(5,0 \%)$ & $11(36,6 \%)$ \\
\hline$\left(<300 \mathrm{~m}^{2}\right)$ & $2(3,3 \%)$ & $2(3,3 \%)$ & $0(0,0 \%)$ & $10(33,3 \%)$ & $5(16,6 \%)$ & $19(63,3 \%)$ \\
\hline Total & $2(3,3 \%)$ & $3(5,0 \%)$ & $0(0,0 \%)$ & $17(56,6 \%)$ & $8(26,6 \%)$ & $30(100,0 \%)$ \\
\hline
\end{tabular}

Sumber : Diolah dari data primer, 2016

Tabel 16. Semakin Berkurangnya Masyarakat Yang Berprofesi Sebagai Petani

\begin{tabular}{lcccc}
\hline Alternatif Jawaban & Alternatif Skor & Jumlah Responden (Orang) & $\begin{array}{c}\text { Persentase } \\
\text { Responden }\end{array}$ & Total Skor (\%) \\
\hline Sangat Setuju & 5 & 3 & 73,3 & 15 \\
Setuju & 4 & 22 & 16,7 & 88 \\
Ragu - ragu & 3 & 5 & 10,0 & 15 \\
Tidak Setuju & 2 & - & - & - \\
Sangat Tidak Setuju & 1 & - & - & - \\
\hline Total & & 30 & 100 & 118 \\
\hline
\end{tabular}

Sumber : Diolah dari data primer, 2016 
Hubungan Antara Karakteristik Individu dengan Sikap Pemilik Lahan Terhadap Alih Fungsi Lahan Nurjanah (2011) dalam Hidayati (2013) menjelaskan dalam penelitiannya bahwa karakteristik individu dapat mempengaruhi sikap. Karakteristik tersebut meliputi usia, pendidikan, tingkat pendapatan, luas lahan pekarangan, status rumah dan pekarangan, dan pengeluaran dalam

keluarga. Penelitian lain dilakukan oleh Pertiwi (2011) dalam Hidayati (2013) yang menjelaskan mengenai faktor internal yang dapat mempengaruhi sikap. Faktor internal tersebut adalah umur, tingkat pendidikan, tingkat pendapatan, dan jumlah tanggungan dalam keluarga. Pada penelitian ini karakteristik individu yang diuji antara lain usia, tingkat pendidikan, status pekerjaan pemilik lahan, jumlah tanggungan dalam keluarga, serta

penguasaan dan luas lahan oleh pemilik lahan. Karakteristik individu yang dihubungkan dengan sikap pemilik lahan terhadap alih fungsi lahan di Desa Kalasey Satu.

\section{Hubungan Antara Usia dengan Sikap Pemilik Lahan terhadap Alih Fungsi Lahan}

Usia merupakan salah satu karakteristik individu yang diduga memiliki hubungan dengan sikap terhadap alih fungsi lahan. Semakin muda usia seseorang diduga akan semakin setuju terhadap alih fungsi lahan. Dugaan ini berawal dari pemikiran bahwa minat generasi muda semakin berkurang terhadap pertanian. Berdasarkan hasil skor (terlampir) ternyata usia pemilik lahan tidak memiliki hubungan sikap yang nyata dengan sikap pemilik lahan terhadap alih fungsi lahan di Desa Kalasey Satu.

Hasil wawancara dengan responden menunjukkan bahwa pemilik lahan yang berusia < 36 tahun, 40-49 tahun, maupun 62-79 tahun hampir memiliki pandangan dan sikap yang sama terhadap adanya alih fungsi lahan, menjadi tempat usaha, perumahan. Bagi mereka, lahan yang dialihfungsikan menjadi tempat usaha, perumahan tidak memberikan jaminan bagi masa depan. Namun alih fungsi lahan menjadi pabrik atau industri masih memberikan harapan bagi mereka yang berusia < 36 tahun untuk bekerja di pabrik atau industri yang dibangun. Berbeda halnya dengan pemilik lahan yang berusia 62-79 tahun, mereka beranggapan bahwa mengelolah lahan adalah pekerjaan yang dapat diandalkan untuk memenuhi kebutuhan pokok.

\section{Hubungan Antara Tingkat Pendidikan dengan Sikap Pemilik Lahan terhadap Alih Fungsi Lahan}

Tingkat pendidikan diduga memiliki hubungan dengan sikap pemilik lahan terhadap alih fungsi lahan. Semakin tinggi tingkat pendidikan diduga semakin menunjukkan sikap tidak setuju terhadap alih fungsi lahan. Dugaan ini berawal dari pemikiran bahwa tingkat pendidikan yang D3 dapat membawa seseorang untuk berpikir jangka panjang. Artinya, individu mampu mempertimbangkan perilaku yang dilakukan saat ini akan memiliki dampak terhadap masa mendatang. Sebaliknya, tingkat pendidikan yang SD, SMP tidak berpikir terhadap masa mendatang sehingga sikap yang ditunjukkan adalah tidak setuju terhadap alih fungsi lahan karena berpikir lahan sebagai tanah warisan untuk masa mendatang.

Hubungan Antara Status Pekerjaan Bertani dengan Sikap Pemilik Lahan terhadap Alih Fungsi Lahan Status pekerjaan utama merupakan karakteristik individu yang diduga memiliki hubungan dengan sikap pemilik lahan terhadap alih fungsi lahan. Status pekerjaan Pengawai Negeri sebagai pekerjaan utama diduga memiliki kecenderungan sikap yang setuju terhadap alih fungsi lahan. Sebaliknya, status pekerjaan Swasta sebagai pekerjaan sampingan memiliki kecenderungan sikap yang setuju terhadap alih fungsi lahan. Dugaan ini berawal dari pemikiran bahwa pemilik lahan sebagai pekerjaan utama memiliki ketergantungan yang lebih tinggi terhadap lahan. Hal ini karena pekerjaan utama adalah pekerjaan yang dianggap lebih mampu memenuhi kebutuhan pokok. Sedangkan pekerjaan sampingan memiliki ketergantungan yang lebih rendah terhadap lahan.

\section{Hubungan Antara Jumlah Tangungan dalam Keluarga dengan Sikap Pemilik Lahan terhadap Alih Fungsi Lahan}

Jumlah tanggungan dalam keluarga diduga memiliki hubungan dengan sikap pemilik terhadap alih fungsi lahan. Semakin banyak jumlah tanggungan dalam keluarga diduga cenderung memiliki sikap tidak setuju terhadap alih fungsi lahan dan sebaliknya. Dugaan ini berawal dari pemikiran bahwa jumlah tanggungan yang banyak membutuhkan biaya yang tidak sedikit. Sedangkan alih fungsi lahan yang terus dilakukan dapat menyebabkan pendapatan mereka berkurang, sehingga kondisi mereka semakin sulit. 
Hubungan Antara Luas dan Penguasaan Lahan oleh Pemilik Lahan dengan Sikap Pemilik Lahan terhadap Alih Fungsi Lahan

Karakteristik individu trerakhir yang diduga berhubungan dengan sikap pemilik lahan terhadap alih fungsi lahan adalah luas dan penguasaan lahan oleh pemilik lahan. Diduga bahwa semakin luas lahan yang dikuasai oleh pemilik lahan maka semakin menunjukkan sikap tidak setuju terhadap alih fungsi lahan. Dugaan ini berawal dari pemikiran bahwa pendapatan pemilik lahan berlahan luas sebagian besar diperoleh dari hasil mengolah lahan maupun di jadikan tempat usaha , sehingga pemilik lahan memiliki ketergantungan yang tinggi terhadap lahan.

Sikap pemilik lahan terhadap alih fungsi lahan tidak dibedakan berdasarkan luas dan penguasaan lahan oleh pemilik lahan sebagai pemilik berlahan luas, pemilik berlahan sempit. Hasil wawancara menunjukkan bahwa beberapa pemilik berlahan baik luas maupun sempit berencana untuk mewariskan lahan tersebut kepada keturunan mereka. Mereka menganggap bahwa nilai lahan akan berubah dari waktu ke waktu (semakin mengalami peningkatan). Oleh karena itu, lahan yang dimiliki lebih baik digunakan untuk investasi bagi masa depan, sehingga sebagian besar sikap yang ditunjukkan adalah tidak setuju terhadap alih fungsi lahan.

\section{Sikap Responden Aspek Kognitif (pikiran)}

Profesi sebagai petani di Kalasey jika dilihat sekarang ini memang ada penuruna . menjadi seorang petani kini bukan lagi menjadi suatu impian, dan itu terbukti ketika semakin berkurangnya masyarakat yang berprofesi sebagian petani. Dapat dilihat pada Tabel 16.

Hasil penelitian ini menunjukan bahwa 73,3 persen responden (22 orang) setuju dengan pernyataan semakin berkurangnya masyarakat yang berprofesi sebagai petani. Sedangkan sisanya sebanyak 16,67 persen responden (5 orang) sangat setuju, dan ragu-ragu hanya 10 persen reponden (3 orang) dengan pernyataan tersebut. Total skor yang diperoleh dari 30 responden pada indikator pernyataan nomor 1 ini adalah sebesar 136. Angka indeks sikap mengenai pernyataan 1 yaitu : $118 / 150 \times 100 \%=$ $78.66 \%$, sehingga interpretasi nilainya tergolong baik karena masyarakat desa Kalasey banyak yang berprofesi sebagai pengawai negeri sipil, swasta dan pekerjaan lainnya.

\section{Alih Profesi Merupakan Salah Satu Penyebab Bertambahnya Alih Fungsi Lahan}

Salah satu penyebab bertambahnya alih fungsi lahan yaitu karena alih profesi , dimana pemilik lahan berpikir bahwa dengan alih profesi misalnya dari petani menjadi pengusaha ternak, tukang bangunan atau pekerjaan lainnya yang lebih menguntungkan. Sikap pemilik lahan terhadap pernyataan ini ditunjukkan pada Tabel perhitungan rekapitulasi.

Hasil penelitian ini menunjukkan bahwa 53,33 persen responden (16 orang) setuju kalau ternyata alih profesi merupakan salah satu penyebab bertambahnya alih fungsi lahan. Sedangkan 6,7 persen responden ( 2 orang ) menjawab sangat setuju dan tidak setuju sebesar 40 persen responden (12 orang) dengan pernyataan tersebut. Total skor yang diperoleh dari 30 responden pada pernyataan nomor 2 ini adalah 98. Angka indeks sikap mengenai pernyataan 2 yaitu : 98/150 x $100 \%=65,33 \%$ sehingga interpretasi nilainya tergolong baik karena pemilik lahan merasa bahwa bisa pekerjaan lain bisa mencukupi kebutuhan hidup yang semakin mahal.

\section{Pekerjaan Tetap Sebagai Swasta / Pengawai Menyebabkan Kurangnya Waktu Luang Untuk Mengalihfungsikan Lahan}

Salah satu alasan tidak lagi mengalihfungsikan lahan yaitu karena sibuk dengan pekerjaannya. Misalnya responden yang berprofesi sebagai pengawai / swasta yang memilih lahanya tidak dialihfungsikan karena pekerjaan menetap.

Hasil penelitian ini menunjukan bahwa 66,6 persen responden (20 orang ) setuju karena pekerjaan tetap sebagai swasta / pengawai menyebabkan kurang waktu luang untuk mengalihfungsikan lahan. Sedangkan sangat setuju 33,3 persen responden (10 orang). Total skor yang dperoleh dari 30 responden pada pernyataan nomor 3 ini adalah sebesar 140. Angka indeks sikap mengenai pernyataan nomor 3 yaitu : 130/150 x 100 $\%=86,66 \%$ sehinga interpretasi nilainya tergolang sangat baik karena pemiliki lahan tidak punya waktu luang lagi untuk mengalihfungsikan lahan karena sibuk dengan pekerjaannya.

\section{Menjual Lahan Akan Memberikan Keuntungan Bagi Pemilik Lahan}

Dengan menjual lahan pastinya akan mendapat keuntungan bagi pemiliki lahan dan bahkan bisa mengganti dengan lahan yang lebih besar. Hasil penelitian ini menunjukan bahwa 66,3 persen responden (19 orang) setuju jika menjual lahan akan memberikan keuntungan bagi pemilik lahan. Sedangkan sangat setuju 36,6 persen 
responden (11 orang). Total skor yang dperoleh dari 30 responden pada pernyataan nomor 4 ini adalah sebesar 139. Angka indeks sikap mengenai pernyataan nomor 4 yaitu : $131 / 150 \times 100 \%=87,33$ $\%$ sehingga interpretasi nilainya masih tergolong sangat baik karena pemiliki lahan menyadari walaupun mereka menjual lahan, namun mereka tahu bahwa jika lahan dijual, tidak putus asa karena bisa mengganti lahan yang lebih besar, maka akan memperoleh keuntungan

\section{Pemiliki Lahan Cenderung Memilih Pekerjaan Sebagai Swasta / Pengawai dibandingkan Menjadi Petani}

Menjadi seorang petani ternyata bukan lagi pilihan bagi generasi muda. Kerena sebagian besar memilih menjadi swasta / pengawai dibandingkan hanya menjadi sesorang petani. Sikap pemilik lahan terhadap pernyataan ini ditunjukkan pada.

Hasil penelitian ini menunjukkan bahwa 80 persen responden (24 orang) setuju bahwa pemiliki lahan cenderung lebih memilij pekerjaan sebagai swasta / pengawai dibandingkan menjadi petani. Sedangkan 20 persen responden (6 orang) masih sangat setuju dengan pernyataan tersebut. Total skor yang diperoleh dari 30 responden pada pernyataan ini sebesar 144. Angaka indeks sikap mengenai pernyataan nomor 5 yaitu : $126 / 150 \times 100 \%=84 \%$ sehingga interpretasi nilainya tergolong sangat baik karena sebagian besar pemilik lahan merasa biaya hidup cukup, karena itu mereka memlilih pekerjaan sebagai swasta / pengawai negeri dan pekerjaan lainnya yang lebih menguntungkan. Sedangkan sebagai pemilik lahan merasa harus bekerja sebagai swasta / pengawai karena latar belakang pendidikan mereka SMA atau D3.

\section{Rekapitulasi Indeks Sikap Pemilik Lahan dari Aspek Kognitif}

Tabel 21 menunjukkan rekapitulasi total skor, indeks sikap dan interpretasi dari sikap pemilik lahan dari aspek kognitif. Tabel 21 menunjukkan bahwa terdapat 5 indikator sikap pemilik lahan yang diukur dalam aspek kognitif dimana pernyataan adalah indeks sikap tertinggi, yaitu 87,33 persen dengan interpretasi tinggi. Sedangkan pernyataan 3 mendapat indeks sikap 86,66 persen pernyataan 5 mendapat indeks sikap 84 persen, pernyataan 1 mendapat indeks sikap 78,66 persen dan pernyataan 2 mendapat indeks sikap 65,33 persen dan semuanya indeks mendapat interpretasi sangan baik, karena interpretasi dengan angka 61 persen- 81 persen itu baik dalam teori Likert yang dikatan oleh Ridwan (2010).

\section{Sikap Responden Aspek Afektif (perasaan ) Merasa Tidak Puas Dengan Hasil Membuka Usaha Sehingga Lahan Dijual}

Sikap seseorang dapat juga dilihat lewat aspek afektif atau perasaan. Salah satumya yaitu adanya ketidakpuasaan seseorang. Seperti halnya dengan pemilik lahan yang merasa tidak puas dengan hasil dari membuka usaha sehingga lahan dijual.

Hasil penelitian ini menunjukkan bahwa 80 persen responden (24 orang ) tidak setuju dengan pernyataan bahwa pemilik lahan merasa tidak puas dengan hasil membuka usaha sehingga lahan dijual, dan ragu-ragu 20 persen responden (6 orang). Total skor yang diperoleh dari 30 rsponden pada pernyataan ini adalah sebesar 84. Angka indeks sikap mengenai pernyataan nomor 6 yaitu : 66/150 x $100 \%=44 \%$ sehingga interpretasi nilainya kurang baik karena pemilik lahan yang tidak pernah merasa puas dan merasa bahwa hasilnya tidak akan cukup untuk membiayai kebutuhan hidup setiap hari.

\section{Merasa Perlu Mengolah Lahan Agar Tidak Perlu Membeli Bahan Pokok}

Harga bahan pokok saat ini mulai naik karena itu dirasa perlu untuk mengelolah lahan agar pemilik lahan tidak perlu mengerluarkan biaya untuk membeli bahan pokok keperluan sehari-hari seperti cabe, tomat dan sebagiannya dengan demikian maka pengeluaran pun akan berkurang.

Hasil penelitian ini menunjukkan bahwa 46,6 persen responden (14 orang ) sangat tidak setuju walaupun responden tidak merasa perlu mengeolah lahan agar tidak membeli bahan pokok, dan 13,3 persen responden (4 orang ) masih tidak setuju dengan pernyataan tersebut karena mereka sendiri tidak mengelolah lahan. Sedangkan 20 persen responden (6 orang) sangat setuju dan setuju dengan pernyataan tersebut karena mereka merasa perlu mengelolah lahan. Total skor yang diperoleh dari 30 responden pada pernyataan ini adalah sebesar 76. Angka indeks sikap mengenai pernyataan nomo 7 yaitu : 76/150 x $100 \%=50,66 \%$ sehingga interpretasi nilainya tergolong kurang baik karena walaupun pemilik lahan menyadari tidak meresa mengelolah lahannya tapi mereka juga tahu bahwa dengan mengelolah lahan maka akan semakin meringankan pengeluaraan untuk membeli bahanbahan pokok sehari-hari seperti tomat, cabe dan lainnya. 
Apakah Alih Fungsi Lahan Bisa Mensejahterakan Perekonomian Penduduk

Kesejahteraan masyarakat bisa didapatkan dengan adanya upaya dan kerja keras dari pekerjaan yang dilakukan. Jika alih fungsi lahan bisa mensejahterakan perekonomian penduduk pasti tidak mengecewakan.

Hasil penelitian ini menunjukkan bahwa 60 persen responden (18 orang) setuju bahwa alih fungsi lahan bisa mensejahterakan perekonomian penduduk. Sedangkan 40 persen responden (12 orang) masih sangat setuju dengan pernyataan tersebut. Total skor yang diperoleh dari 30 responden pada pernyataan ini adalah sebesar 132 . Angka indeks sikap mengenai pernyataan nomor 8 yaitu : $132 / 150 \times 100 \%=88 \%$ sehingga interpretasi nilainya tergolong sangat baik karena pemilik lahan tahu bahwa ketika masyarakat menekuni pekerjaannya dengan baik maka hasilnya bisa untuk mensejahterakan penduduk.

\section{Ingin Mendapatkan Hasil Yang Lebih Dengan Mencari Pekerjaan Yang Lain}

Mendapatkan pekerjaan dengan penghasilan yang banyak menjadi tujuan kebanyakan orang termaksuk pemilik lahan. Ketika pemilik lahan merasa hasil dari lahannya sangat sedikit maka ada perasaan ingin mencari pekerjaan yang lain selain mengalihfungsikan lahan.

Hasil penelitian ini menunjukkan bahwa 66,6 persen responden ( 20 orang) setuju bahwa ingin mendapatkan hasil yang lebih dengan mencari pekerjaan lain. Sedangkan 33,3 persen responden (10 orang) masih sangat setuju dengan pernyataan tersebut. Total skor yang diperoleh dari 30 responden pada pernyataan ini adalah sebesar 130 . Angka indeks sikap mengenai pernyataan nomor 9 yaitu : 130/150 x $100 \%=86,66 \%$ sehingga interpretasi nilainya tergolong sangat baik karena rasa tidak puas membuat pemilik lahan ingin mencari lagi pekerjaan yang lain untuk penghasilan yang lebih besar.

\section{Sering Mengalami Kerugian Saat Mengalihfungsikan Lahan Karena Pengeluaran Lebih Besar Dari Pada Hasil Yang Didapat}

Resiko saat mengelolah lahan yaitu ketika mengalami kerugian. Terkadang pengeluaran lebih besar dari hasil yang didapat sehingga menyebabkan banyak pemilik lahan mengalihfungsikan lahannya. Hasil penelitian ini menunjukakan bahwa 36,6 persen responden (11 orang) sangat setuju dan tidak setuju bahwa sering mengalami kerugian mengalihfungsikan lahan karena pengeluaran lebih besar dari pada hasil yang didapat. 26,7 persen responden ( 8 orang ) setuju, sedangkan tidak setuju
36,7 persen responden (11 orang ) dengan pernyataan tersebut. Total skor yang diperoleh dari 30 responden pada pernyataan ini adalah sebesar 109. Angka indeks sikap mengenai pernyataan nomor 10 yaitu : 109/150 x $100 \%=72,66 \%$ sehingga interpretasi nilainya tergolong baik karena ada beberapa memilik lahan yang saat kerugian saat mengalihfungsikan lahan, dan pemilik lainnya juga setuju bahwa seringkali karena kerugian, banyak yang memilih tidak lagi mengalihfungsikan lahannya karena pengeluaran tidak lagi sebanding dengan hasil yang didapat.

\section{Rekapitulasi Indeks Sikap Pemilik Lahan dari Aspek Afektif}

Tabel 27 menunjukkan rekapitulasi total skor, indeks sikap dan interpretasi dari sikap pemilik lahan dari aspek afektif. Tabel 27 menunjukkan bahwa terdapat 5 indikator sikap pemilik lahan yang diukur dalam aspek afektif dimana pernyataan dimana pernyataan 5 adalah indeks sikap tertinggi, yaitu 88 persen dengan interpretasi tinggi. Sedangkan pernyataan 8 mendapat indeks sikap 86,66 persen pernyataan 10 mendapat indeks sikap 72,66 persen, pernyataan 6 mendapat indeks sikap 56 persen dan pernyataan 7 mendapat indeks sikap 50,66 persen dan semuanya indeks mendapat interpretasi sangan baik,karena interpretasi dengan angka 61 persen- 81 persen itu sangat baik dalam teori Likert yang dikatan oleh Ridwan (2010).

\section{Sikap Responden Aspek Konatif (kecenderungan bertingkah laku)}

\section{Kecenderungan Untuk Konsumsi Keluarga Seiring Dengan Perekonomian Yang Semakin Besar}

Dalam kecenderungan bertingkah laku seiring dengan perekonomian yang semakin besar. Ada pemilik lahan yang mengalihfungsikan lahannya khusus untuk dikonsumsi keluarga atau kebutuhan keluarga begitu besar, jadi hasil mengalihfungsikan lahan dan hasilnya tidak dijual. Dan mengalihfungsikan lahan pasti tidak memerlukan modal yang besar karena hanya bahan pokok saja yang biasa dikonsumsi setiap hari.

Hasil penelitian ini menunjukkan bahwa 90 persen responden (27 orang) setuju bahwa di desa Kalasey masyarakat cenderung mengalihfungkan lahan hanya untuk kebutuhan keluarganya, 6,7 persen responden (2 orang). Sedangkan, (1 orang) masih tidak setuju dengan pernyataan tersebut karena menyadari bahwa lahan mereka dialihfungsikan. Total skor yang 
diperoleh dari 30 responden pada pernyataan nomor 11 yaitu: $115 / 150 \times 100 \%=76,66 \%$ sehingga interpretasi nilainya tergolong baik karena didesa Kalasey ada yang mengalihfungsikan lahannya untuk kebutuhan keluarga agar biaya yang dikeluarkan untuk kebutuhan keluarga tidak terlalu banyak.

\section{Kecenderungan Akan Menyebabkan Semakin Meningkatnya Permintaan Terhadap Alih Fungsi Lahan}

Kecenderungan akan menyebabkan semakin meningkatnya permintaan terhadap alih fungsi lahan. Biaya memang semakin besar karena permintaan terhadap alih fungsi lahan semakin meningkat, dimana semakin bertambahnya masyarakat untuk melakukan permintaan terhadap alih fungsi lahan.

Hasil penelitian ini menunjukkan bahwa 86 persen responden (26 orang) setuju bahwa kecenderungan akan menyebabkan semakin meningkatnya permintaan terhadap alih fungsi lahan. Dan 10 persen responden (3 orang) raguragu, sedangkan 3,3 persen responden (1 orang) masih sangat setuju dengan pernyataan tersebut. Total skor yang diperoleh dari 30 responden pada pernyataan ini adalah sebesar 115. Angka indeks sikap mengenai peryataan nomor 12 yaitu : $115 / 150 \times 100 \%=76,66 \%$ sehingga interpretasi nilainya tergolong baik karena semakin meningkatnya permintaan terhadap alih fungsi lahan di Desa Kalasey Satu.

\section{Kecenderungan Ketersediaan Lahan Yang Relatif Tetap Akan Menyebabkan Tingginya Penggunaan Lahan Dalam Berbagai Alternatif Penggunaannya Seperti Sektor Industri, Pemukiman}

Ketersediaan lahan yang relativf tetap akan menyebabkan tingginya kompetisi penggunaan lahan dalam berbagai alternatif, karena banyak pemilik lahan yang penggunaannya seperti disektor industr, pemukiman. Hasil penelitian ini menunjukkan bahwa 70 persen responden (21 orang) setuju bahwa kecenderungan ketersediaan lahan yana relatif akan menyebabkan tingginya penggunaan lahan dalam berbagai alternatif penggunaanya seperti sektor industry, pemukiman. Dan 26,7 persen responden (8 orang) sangat setuju, sedangkan 3,3 persen responden ( 1 orang) masih sangat tidak setuju dengan pernyataan tersebut. Total skor yang diperoleh dari 30 responden pada pernyataan nomor 13 yaitu : $125 / 150 \times 100 \%=83,33$ sehingga interpretasi nilainya tergolong baik karena sebagian pemilik lahan merasa ketersediaan lahan yang relatif tetap akan menyebabkan tingginya penggunaan lahan dalam berbagai alternatif penggunaannya seperti disektor industri, pemukiman.

\section{Kecenderungan Mengalihfungsikan Lahan Untuk Mendapat Keuntungan Yang Besar \\ Kecenderungan pemilik lahan untuk} mengalihfungsikan lahan antara lain yaitu supaya mendapat keuntungan yang besar. Banyak pemilik lahan yang bisa dikatakan berhasil karena tau bagaimana mengalihfungsikan lahan agar mendapat keuntungan yang besar.

Hasil penelitian ini menunjukan bahwa 73,3 persen responden (22 orang) sangat setuju bahwa banyak yang cebderung mengalihfungsikan lahan untuk mendapat keuntungan yang besar. Mereka sangat setuju karena melihat ada yang berhail mendapatkan untung yang besar ketika mengalihfungsikan lahan. 20 persen responden (6 orang) setuju, sedangkan 6,6 persen ( 2 orang) masih ragu-ragu dengan pernyataan tersebut karena mereka tidak mengalihfungsikan lahan. Total skor yang diperoleh dari 30 responden pada pernyataan ini adalah sebesar 140. Angka indeks sikap mengenai pernyataan nomor 14 yaitu : 140/150 x $100 \%=$ $93,33 \%$ sehingga interpretasi nilainya tergolong sangat baik karena pemilik lahan tahu bahwa banyak yang ingin mengalihfungsikan lahan hanya karena ingin mendapatkan keuntungan besar tanpa memikirkan ketika mengalami kerugian.

\section{Kecenderungan Tidak Mengalihfungsikan Lahan Karena Kondisi Yang Semakin Padat Dengan Kependudukan}

Kondisi yang semakin padat dengan kepeduduk mengahambat pemilik lahan untuk mengalihfungsikan lahannya. Keinginan dan semangat untuk mengalihfungsikan lahan terpaksa menjadi terhambat karena kondisi semakin padat kependudukan dan pemilik lahanpun sudah sedikit.

Hasil penelitian ini menunjukkan bahwa 56,6 persen responden (17 orang) setuju bahwa banyak yang cenderung tidak mengalihfungsikan lahan karena kondisi yang semakin padat dengan penduduk dang pemilik lahan sudah sedikit lahannya. Total skor yang diperoleh dari 30 
responden pada pernyataan ini adalah sebesar 96. Angaka indeks sikap mengenai pernyataan nomor 15 yaitu : 96/150 x $100 \%=64 \%$ sehingga interpretasi nilainya tergolong baik.

\section{Rekapitulasi Indeks Sikap Pemilik Lahan dari Aspek Konatif}

Tabel 33 menunjukkan bahwa terdapat 5 indikator sikap pemilik lahan yang di ukur dalam aspek konatif dimana pernyataan 14 adalah indeks sikap tertinggi, yaitu 93,33 persen, pernyataan 13 mendapat indeks sikap 80,66 persen, pernyataan 11 mendapat indeks sikap 77,33, pernyataan 12 mendapat indeks sikap 76,66 persen dan pernyataan 15 mendapat indeks sikap 64 persen. Dan semuanya mendapat interpretasi sangat baik.

\section{Rekapitulasi Indeks Sikap Pemilik Lahan terhadap Alih Fungsi Lahan pada Masing- Masing Indikator dan Interpretasi Hasil}

Penelitian untuk mengukur sikap pemilik lahan terhadap alih fungsi lahan yang diterapkan mengambilan 15 indikator sebagai tolak ukur dalam penelitian ini, dimana masing-masing terbagi dalam 3 (tiga) bagian yaitu aspek kognitif, aspek afektif, dan aspek konatif. Tabel 34 menunjukakan bahwa semua indikator mendapatkan skor pada indeks yang tergolong baik (61-100\%). Walaupun pada indikator 14 yakni aspek konatif hanya skor 93,33 persen namun masih tergolong sangat baik. Hal ini menunjukkan bahwa dalam sikap tergolong sangat baik terhadap alih fungsi lahan di desa Kalasey satu. Untuk mengetahui letak sikap pemilik lahan terhadap alih fungsi lahan, maka perlu dihitung jumlah keseluruhan skor pada setiap kriterium, dimana sesuai hasil penelitian ini skor mencapai 1.779. Pada penelitian ini, jumlah skor ideal (skor tertinggi), yaitu 2.250 (tinggi) dan jumlah skor terendah yaitu 450 (rendah). Berdasarkan data yang dihimpun dari sebanyak 15 instrumen pernyataan yang diajukan kepada 30 responden, maka diperoleh total skor 2.250 dengan letak indeks ditentukan berdasarkan skala likert berikut :

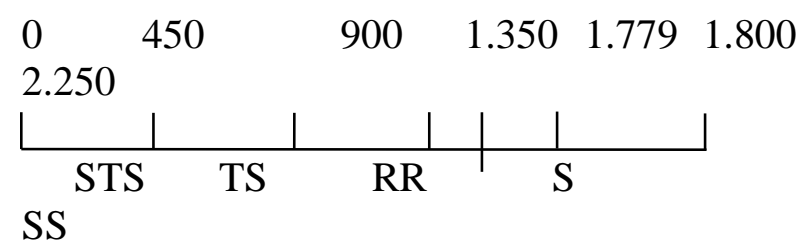

Secara presentase, angka indeks sikap pemilik lahan terhadap alih fungsi lahan terletak pada :

$$
\begin{gathered}
\text { Tingkat Sikap }=\frac{\text { Jumlah Skor Hasil Pengumpulan Data }}{\text { Jumlah Skor Ideal }(\text { Tertinggi })} \times 100 \% \\
=\frac{1779}{2250} \times 100 \%=79,06 \%
\end{gathered}
$$

Dengan Interpretasi nilai :

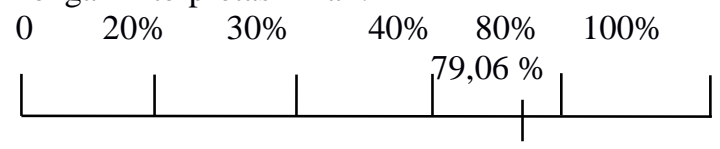

Berdasarkan hasil analisis menggunakan skala likert, maka dapat diketahui bahwa angaka indeks sikap pemilik lahan terhadap alih fungsi lahan berada pada titik 73,73 persen dan tergolong baik.

Tabel 21. Rekapitulasi Jumlah Skor Pengambilan Data, Indeks Sikap, dan Interpretasi pada

\begin{tabular}{|c|c|c|c|}
\hline Pernyataan & Total Skor & Indeks Sikap (\%) & Interpretasi \\
\hline $\begin{array}{lll}\text { Semakin berkurangnya } & \text { masyarakat } & \text { yang } \\
\text { berprofesi sebagai petani } & & \end{array}$ & 136 & 78,66 & Baik \\
\hline $\begin{array}{l}\text { Alih profesi merupakan salah satu penyebab } \\
\text { bertambahnya alih fungsi lahan }\end{array}$ & 98 & 65,33 & Baik \\
\hline $\begin{array}{l}\text { Pekerjaan tetap sebagai swasta / pengawai } \\
\text { menyebabkan kurangnya waktu luang untuk } \\
\text { mengalihfungsikan lahan }\end{array}$ & 140 & 86,66 & Sangat baik \\
\hline $\begin{array}{l}\text { Menjual lahan akan memberikan keuntungan bagi } \\
\text { pemiliki lahan }\end{array}$ & 139 & 87,33 & Sangat baik \\
\hline $\begin{array}{l}\text { Pemiki lahan cenderung memilih pekerjaan } \\
\text { sebagai swasta / pengawai dibandingkan menjadi } \\
\text { petani }\end{array}$ & 144 & 84 & Sangat baik \\
\hline
\end{tabular}
Indikator Sikap Pemilik Lahan Aspek Kognitif

Sumber : Diolah dari data primer, 2016 
Tabel 27. Rekapitulasi Jumlah Skor Pengambilan Data, Indeks Sikap, dan Interpretasi pada Indikator Sikap Pemilik Lahan Aspek Afektif

\begin{tabular}{|c|c|c|c|}
\hline Pernyataan & $\begin{array}{l}\text { Total } \\
\text { Skor }\end{array}$ & $\begin{array}{c}\text { Indeks Sikap } \\
(\%)\end{array}$ & $\begin{array}{c}\text { Interpreta } \\
\text { si }\end{array}$ \\
\hline $\begin{array}{l}\text { Merasa tidak puas dengan hasil membuka usaha } \\
\text { sehingga lahan dijual }\end{array}$ & 66 & 44 & $\begin{array}{c}\text { Kurang } \\
\text { baik }\end{array}$ \\
\hline $\begin{array}{l}\text { Merasa perlu mengolah lahan agar tidak perlu membeli } \\
\text { bahan pokok }\end{array}$ & 76 & 50,66 & $\begin{array}{c}\text { Kurang } \\
\text { baik }\end{array}$ \\
\hline $\begin{array}{l}\text { Apakah alih fungsi lahan bisa mensejahterakan } \\
\text { perekonomian penduduk }\end{array}$ & 132 & 88 & $\begin{array}{l}\text { Sangat } \\
\text { baik }\end{array}$ \\
\hline $\begin{array}{l}\text { Ingin mendapatkan hasil yang lebih dengan mencari } \\
\text { pekerjaan yang lain }\end{array}$ & 130 & 86,66 & $\begin{array}{l}\text { Sangat } \\
\text { baik }\end{array}$ \\
\hline $\begin{array}{l}\text { Sering mengalami kerugian saat mengalihfungsikan } \\
\text { lahan karena pengeluaran lebih besar dari pada hasil } \\
\text { yang didapat }\end{array}$ & 109 & 72,66 & $\begin{array}{l}\text { Sangat } \\
\text { baik }\end{array}$ \\
\hline
\end{tabular}

Sumber : Diolah dari data primer, 2016

Tabel 33. Rekapitulasi Jumlah Skor Pengambilan Data, Indeks Sikap, dan Interpretasi pada Indikator Sikap Pemilik Lahan Aspek Konatif

\begin{tabular}{|c|c|c|c|}
\hline Pernyataan & $\begin{array}{l}\text { Total } \\
\text { Skor }\end{array}$ & $\begin{array}{c}\text { Indeks } \\
\text { Sikap }(\%) \\
\end{array}$ & Interpretasi \\
\hline $\begin{array}{l}\text { Kecenderungan untuk konsumsi keluarga seiring } \\
\text { dengan perekonomian yang semakin besar }\end{array}$ & 115 & 76,66 & Sangat baik \\
\hline $\begin{array}{l}\text { Kecenderungan akan menyebabkan semakin } \\
\text { meningkatnya permintaan terhadap alih fungsi } \\
\text { lahan }\end{array}$ & 115 & 76,66 & Sangat baik \\
\hline $\begin{array}{l}\text { Kecenderungan ketersediaan lahan yang relatif tetap } \\
\text { akan menyebabkan tingginya penggunaan lahan } \\
\text { dalam berbagai alternatif penggunaannya seperti } \\
\text { sektor industri, pemukiman }\end{array}$ & 125 & 83,33 & Sangat baik \\
\hline $\begin{array}{l}\text { Kecenderungan mengalihfungsikan lahan untuk } \\
\text { mendapat keuntungan yang besar }\end{array}$ & 140 & 93,33 & Sangat baik \\
\hline $\begin{array}{l}\text { Kecenderungan tidak mengalihfungsikan lahan } \\
\text { karena kondisi yang semakin padat dengan } \\
\text { kependudukan }\end{array}$ & 96 & 64 & Baik \\
\hline
\end{tabular}


Tabel 34. Rekapitulasi Total Skor, Indeks dan Interpretasi Hasil

\begin{tabular}{|c|c|c|c|}
\hline Pernyataan & $\begin{array}{l}\text { Total } \\
\text { Skor }\end{array}$ & $\begin{array}{c}\text { Indeks Sikap } \\
(\%)\end{array}$ & Interpretasi \\
\hline $\begin{array}{lll}\text { Semakin berkurangnya } & \text { masyarakat } & \text { yang } \\
\text { berprofesi sebagai petani } & & \\
\end{array}$ & 136 & 78,66 & Baik \\
\hline $\begin{array}{l}\text { Alih profesi merupakan salah satu penyebab } \\
\text { bertambahnya alih fungsi lahan }\end{array}$ & 98 & 65,33 & Baik \\
\hline $\begin{array}{l}\text { Pekerjaan tetap sebagai swasta / pengawai } \\
\text { menyebabkan kurangnya } \\
\text { mengaktu luang untuk } \\
\text { mengsikan lahan }\end{array}$ & 140 & 86,66 & Sangat baik \\
\hline $\begin{array}{l}\text { Menjual lahan akan memberikan keuntungan bagi } \\
\text { pemiliki lahan }\end{array}$ & 139 & 87,33 & Sangat baik \\
\hline $\begin{array}{l}\text { Pemiki lahan cenderung memilih pekerjaan } \\
\text { sebagai swasta / pengawai dibandingkan menjadi } \\
\text { petani }\end{array}$ & 144 & 84,66 & Sangat baik \\
\hline $\begin{array}{l}\text { Merasa tidak puas dengan hasil membuka usaha } \\
\text { sehingga lahan dijual }\end{array}$ & 84 & 44 & Kurang baik \\
\hline $\begin{array}{l}\text { Merasa perlu mengolah lahan agar tidak perlu } \\
\text { membeli bahan pokok }\end{array}$ & 76 & 50,66 & Kurangbaik \\
\hline $\begin{array}{l}\text { Apakah alih fungsi lahan bisa mensejahterakan } \\
\text { perekonomian penduduk }\end{array}$ & 132 & 88 & Sangatbaik \\
\hline $\begin{array}{l}\text { Ingin mendapatkan hasil yang lebih dengan } \\
\text { mencari pekerjaan yang lain }\end{array}$ & 130 & 86,66 & Sangat baik \\
\hline $\begin{array}{l}\text { Seringmengalami } \quad \text { kerugian } \\
\text { mengalihfungsikan lahan karena pengeluaranlebih } \\
\text { besar dari pada hasil yang didapat }\end{array}$ & 112 & 72,66 & Baik \\
\hline $\begin{array}{l}\text { Kecenderungan untuk konsumsi keluarga seiring } \\
\text { dengan perekonomian yang semakin besar }\end{array}$ & 116 & 76,66 & Baik \\
\hline $\begin{array}{l}\text { Kecenderungan akan menyebabkan semakin } \\
\text { meningkatnya permintaan terhadap alih fungsi } \\
\text { lahan }\end{array}$ & 115 & 76,66 & Baik \\
\hline $\begin{array}{l}\text { Kecenderungan ketersediaan lahan yang relatif } \\
\text { tetap akan menyebabkan tingginya penggunaan } \\
\text { lahan dalam berbagai alternatif penggunaannya } \\
\text { seperti sektor industri, pemukiman }\end{array}$ & 121 & 83,33 & SangatBaik \\
\hline $\begin{array}{l}\text { Kecenderungan mengalihfungsikan lahan untuk } \\
\text { mendapat keuntungan yang besar }\end{array}$ & 140 & 93,33 & Sangat baik \\
\hline $\begin{array}{l}\text { Kecenderungan tidak mengalihfungsikan lahan } \\
\text { karena kondisi yang semakin padat dengan } \\
\text { kependudukan }\end{array}$ & 96 & 64 & Baik \\
\hline
\end{tabular}




\section{KESIMPULAN DAN SARAN}

\section{Kesimpulan}

Sikap ini menunjukkan bahwa sebagian besar pemilik lahan di Desa Kalasey Satu tidak menerima terhadap alih fungsi lahan. Hasil pengolahan data penelitian menujukkan bahwa sikap pemilik terhadap alih fungsi lahan tidak memiliki hubungan nyata dengan karakteristik individu, yakni usia, tingkat pendidikan, jumlah tanggungan dalam keluarga, serta luas dan penguasaan lahan oleh pemilik lahan. Sikap pemilik lahan yang diukur dengan skala likert menunujukkan pengaruh sikap kognitif, afektif, dan konatif. Berdasarkan hasil analisi skala likert maka dapat diketahui angka indeks sikap pemilik lahan terhadap alih fungsi lahan berada pada titik 73,73 persen dan tergolong baik. Sikap pemilik lahan menunjukakan bahwa semua indikator mendapatkan skor pada indeks yang tergolong sangat baik (61-100\%). Walaupun pada indikator 14 yakni aspek konatif hanya skor 93,33 persen namun masih tergolong sangat baik. Hal ini menunjukkan bahwa dalam sikap tergolong sangat baik terhadap alih fungsi lahan di desa Kalasey satu

\section{Saran}

Berdasarkan hasil penelitian dan pembahasan, beberapa saran direkomendasikan sebagai bahan pertimbangan, sebagai berikut:

1. Pemerintah perlu meninjau ulang kebijakan perizinan pembangunan yang dilakukan di lahan pertanian terutama untuk keperluan industri dan perumahan di Kabupaten Minahasa. Kebijakan Rencana Tata Ruang Wilayah perlu diperkuat sehingga mampu mengendalikan alih fungsi lahan pertanian.

2. Penyuluhan terhadap masyarakat yang memiliki lahan mengenai pentingnya pertanian terutama lahan perlu ditingkatkan untuk mempertahankan produktifitas sehingga hasil pengolahan yang diperoleh semakin besar, meningkatkan pendapatan masyarakat pemilik lahan, dan menyukseskan program ketahanan sumberdaya alam.

\section{DAFTAR PUSTAKA}

Amalia, S, N, 2014. Analisis Dampak Ekonomi Dari Ahli Fungsi Lahan Pertanian Ke Non Pertanian Terhadap Ketahanan Pangan Di Kabupaten Bogor. Skripsi, Departemen Ekonomi Sumberdaya Dan Lingkungan Fakultas Ekonomi Dan Manajemen Institut Pertanian Bogor.

Andhika, N, K, 2013. Faktor-faktor yang Mempengaruhi Alih Fungsi Lahan Sawah Serta Dampaknya Terhadap Produksi Padi Di Kota Depok. Skripsi, Departeman Ekonomi Sumberdaya Dan Lingkungan Fakultas Ekonomi Dan Manajemen Institit Pertanian Bogor.

Astuti DI. 2011. Keterkaitan Harga Lahan Terhadap Laju Konversi Lahan Pertanian di Hulu Sungai Ciliwung Kabupaten Bogor. Skripsi. Institut Pertanian Bogor, Bogor.

Badan Pusat Statistik. 2015. Pertumbuhan Ekonomi Indonesia. Ekonomi Indonesian Triwulan IV-2015 Tumbuh 5,04 Persen Tertinggi Selama Tahun 2015.

Badan Pusat Statistik. 2015. Statistik Kecamatan Mondolang Kabupaten Minahasa.

Hidayati, H, N. 2013. Konversi Lahan Pertanian Dan Sikap Petani Di Desa Cihideung Ilir Kabupaten Bogor (skripsi). Departemen Sains Komunikasi Dan Pemgembangan Masyarakat, Fakultas Ekologi Manusia Intitut Pertanian Bogor.

Puspasari, A, 2012. Faktor-Faktor Yang Mempengaruhi Ahli Fungsi Lahan Pertanian Dan Dampaknya Terhadap Pendapatan Petani (Studi Kasus Desa Kondangjaya, Kecamatan Karawang Timur Kabupaten Karawang. Skripsi, Departemen Ekonomi Sumberdaya Dan Lingkungan Fakultas Ekonomi Dan Manajemen Institut Petanian Bogor.

Umar H. 2003. Metode Riset Perilaku Konsumen Jasa. Jakarta: Ghalia Indonesia

Yudhistira, M, D, 2013. Analisis Dampak Ahli Fungsi Lahan Pertanian Terhadap Ketahanan Pangan Di Kabupaten Bekasi Jawa Barat (Studi Kasus Desa Sriamur Kecamatan Tambun Utara). Skripsi, Departemen Ekonomi Dan Manajemen Institut Pertanian Bogor. 